Plano Real 



\title{
O Plano Real à luz da experiência mexicana e argentina
} paulo Nogueira Batista JR.

\begin{abstract}
A REForma mONETÁria e cambial de julho de 1994 foi considerada, desde o início, como um marco no processo de adaptação da política econômica 1 brasileira ao padrão de política econômica vigente em grande parte da América Latina. Até então, o desempenho da economia brasileira, especialmente em matéria de inflação, destoava dos resultados alcançados no resto da região, inclusive na Argentina, na Bolívia, na Nicarágua e no Peru, países que como o Brasil haviam experimentado surtos hiperinflacionários na década de 80 ou no início dos anos 90 .
\end{abstract}

A finalidade deste trabalho é analisar os primeiros dois anos do Plano Real, em especial os seus efeitos sobre as relações econômicas externas do Brasil à luz da experiência de programas de estabilização semelhantes adotados no México, a partir de 1988, e na Argentina, desde 1991. A análise concentrar-se-á, portanto, basicamente no período que vai da introdução da nova moeda, em julho de 1994, até meados de 1996.

Em maio de 1993, com a nomeação de Fernando Henrique Cardoso para o Ministério da Fazenda, teve início a montagem de um programa econômico que revelaria grande eficácia em matéria de combate à inflação e resultaria no alinhamento de aspectos centrais da política econômica do país ao modelo de estabilização e integração internacional que vinha sendo aplicado em outros países da América Latina, particularmente no México e na Argentina. A economia brasileira repetiria a trajetória mexicana e argentina em alguns pontos importantes, combinando sucesso inicial no combate à inflação com elevados déficits externos e forte dependência de fluxos voláteis de capital internacional.

Evidentemente, cada experiência nacional apresenta as suas especificidades. Não é difícil apontar diferenças significativas entre o Plano Real, o Plano Cavallo e o programa mexicano. Por exemplo: o Plano Real é claramente mais flexível e cauteloso do que a lei de conversibilidade argentina; o plano mexicano recorreu intensamente a políticas de preços e salários, negociadas em escala nacional com representantes de empresários e trabalhadores, elemento ausente dos programas argentino e brasileiro; no caso do Plano Real, a desindexação foi alcançada de forma original com a criação da Unidade Real de Valor - URV.

As diferenças não impedem, contudo, que esses programas de combate à inflação sejam considerados de forma conjunta, como exemplos de um mesmo modelo geral de estabilização e integração internacional aplicado a diversos países 
da América Latina nos últimos anos. O modelo inclui os seguintes elementos centrais:

- uso da taxa de câmbio como instrumento de combate à inflação;

- abertura da economia às importações, por meio da drástica redução das barreiras tarifárias e não-tarifárias;

- abertura financeira externa, com a adoção inclusive de políticas de estímulo à entrada de capitais externos de curto prazo;

- medidas de desindexação da economia;

- ajuste fiscal e austeridade monetária;

- venda de empresas públicas.

Todos esses aspectos estão presentes, com maior ou menor intensidade, nas políticas econômicas recentes dos três principais países da América Latina. Vejamos como os diversos elementos se articulam entre si.

\section{México, Argentina e Brasil}

Nos três casos, especialmente na Argentina e no Brasil, os programas de estabilização tiveram de enfrentar inflações muito altas segundo padrões internacionais. Prevaleceu a percepção de que a estabilização monetária exigia, nessas circunstâncias, o uso da taxa de câmbio com o dólar como âncora nominal. Isso significou assumir compromissos mais ou menos rígidos com uma trajétória predeterminada para a taxa de câmbio nominal, sacrificando em larga medida a possibilidade de utilizá-la como instrumento de ajuste do balanço de pagamentos.

Como recorda McKinnon (1994:165-166), os economistas estão divididos em duas abordagens conflitantes sobre o papel da taxa de câmbio. A primeira, que o autor denomina international adjustment approach (enfoque ou abordagem do ajustamento internacional), é mais popular entre os especialistas em economia internacional e remonta ao modelo de elasticidades da balança comercial; nessa abordagem a taxa cambial é considerada como variável de ajustamento útil, freqüentemente indispensável, para equilibrar as transações internacionais. A segunda abordagem, denominada monetary standard approach (abordagem do padrão monetário), é mais do campo dos especialistas em economia monetária, às vezes mais propensos a limitar as flutuações da taxa de câmbio e a utilizá-la como fator de harmonização das políticas monetárias de diferentes países e instrumento de combate à inflação. Naturalmente, esta segunda abordagem tende a ganhar força após períodos de prolongada instabilidade monetária.

Foi o que aconteceu em diversos países da América Latina, desde o final dos anos 80. A função primordial da política cambial passou a ser a de contribuir para a convergência da inflação doméstica à inflação internacional, fossem quais fossem os efeitos em termos de perda de competitividade internacional e desequilíbrios no balanço de pagamentos em conta corrente. 
Na prática, o câmbio nominal estável ou prefixado, combinado com a abertura do mercado interno às importações, funcionou como fator de repressão à alta dos preços internos, ao disciplinar os reajustes dos bens comerciáveis internacionalmente, isto é, os importados, os exportáveis e aqueles produzidos com insumos importados ou exportáveis (Carvalho, 1995:147). A menos que houvesse convergência imediata da inflação doméstica à internacional - algo que nem a teoria, nem a vasta experiência com processos de estabilização ancorados no câmbio teriam permitido esperar -, a estabilização cambial tenderia a produzir perda de competitividade internacional.

As perdas de competitividade acabaram sendo muito significativas, uma vez que a convergência da inflação foi bastante lenta. No caso da Argentina, a inflação só foi trazida para o nível registrado nos EUA em meados de 1994, cerca de três anos após o lançamento do programa (1). No caso do México, a inflação nunca chegou a convergir plenamente. Antes do colapso cambial de fins de 1994, a inflação mexicana ainda estava em torno de 7\% a.a., mais do que o dobro da observada nos EUA (2). Nesse contexto de lenta convergência da inflação, a perda de competitividade internacional decorrente da forte valorização da taxa de câmbio bilateral com o dólar dificilmente poderia ser compensada com ganhos internos de produtividade ou desvalorização do dólar com relação a outras moedas relevantes para os países em questão.

Não por acaso, traços comuns a essas experiências foram o crescimento explosivo das importações e a acumulação de déficits expressivos na balança comercial e no balanço de pagamentos em transações correntes, em conseqüência não apenas da valorização cambial, mas também da abertura do mercado interno às importações e - nos casos argentino e brasileiro, mas não no mexicano - da forte expansão da demanda interna que se seguiu à queda da inflação. O México registrou, entre 1988 e 1994, déficit total em conta corrente de nada menos que US\$ 109,8 bilhões. A Argentina acumulou déficits em conta corrente no total de US\$ 24,6 bilhões no período de 1991 a 1994 (3).

Ao contrário dos déficits em conta corrente registrados na fase anterior de endividamento acelerado das economias latino-americanas nos anos 70 até o início dos anos 80 , esses déficits recentes não podem ser atribuídos a choques externos. Algumas variáveis exógenas importantes, notadamente as taxas de juro em dólares, atuaram inclusive no sentido de minorar os desequilíbrios correntes dos países devedores da América Latina até 1993. Por exemplo, a LIBOR (taxa interbancária de Londres) para operações de seis meses em dólares caiu de uma média de 8,8\% ao ano em 1989-90 para 6,1\% em 1991, 3,9\% em 1992 e apenas 3,4\% em 1993 (4). Não obstante, tanto no caso do México como no da Argentina, os déficits correntes cresceram de forma quase contínua nesse período.

Desse modo, ainda que o lançamento desses programas de estabilização tenha sido antecedido em todos os casos, e particularmente no caso do Plano Real, de esforço apreciável na formação de reservas cambiais, não teria sido possível sustentá-los por muito tempo sem que fosse atendida uma premissa funda- 
mental, qual seja, a da disponibilidade de capitais externos (inclusive repatriação de fundos de residentes aplicados no exterior) em montante suficiente para financiar os desequilíbrios de balanço de pagamentos produzidos pela combinação de valorização cambial com abertura às importações. Sem tal premissa, o próprio esforço prévio de acumulação de reservas não teria sido possível na escala em que ocorreu.

A abertura financeira externa e a disposição de adotar políticas monetárias, tributárias e cambiais compatíveis com a atração de capitais especulativos constituem, assim, aspectos centrais do modelo de política econômica seguido nos três países. A razão disso é clara: a possibilidade de atrair capital externo de maior estabilidade e em condições mais favoráveis de prazo e custo depende, em grande medida, do restabelecimento da confiança e da credibilidade internacional do país. Como essa credibilidade vai sendo conquistada aos poucos e os desequilíbrios externos em conta corrente aparecem com grande rapidez, a dependência com relação a capitais de curto e médio prazos instala-se quase que inevitavelmente. $\mathrm{O}$ crescimento do déficit em conta corrente e as evidências de sobrevalorização cambial podem inclusive contribuir para retardar a recuperação da credibilidade e reforçar a dependência de capitais especulativos de curto prazo.

A política fiscal desempenha, nesse contexto, a função de viabilizar a ancoragem cambial. A ela cabe primordialmente impedir que déficits fiscais, nãofinanciados com endividamento externo ou interno de médio e longo prazos, ameacem a sustentação do câmbio, tornando o programa mais vulnerável a ataques especulativos. Essa subordinação da política fiscal à estabilização cambial decorre, evidentemente, da preocupação de evitar que um desequilíbrio crescente entre a liquidez em moeda nacional (na forma de base monetária e títulos públicos de curto prazo) e as reservas cambiais do Banco Central force este último a praticar taxas de juro excessivamente elevadas, em caráter permanente, e acabe criando condições para ataques especulativos bem-sucedidos contra as metas cambiais anunciadas pelo governo.

A privatização, embora justificada, às vezes enganosamente, com apelos genéricos à eficiência da gestão privada e dos mecanismos de mercado, só pode ser plenamente entendida no contexto macroeconômico já delineado. Do ponto de vista do modelo de estabilização adotado nesses países, a venda de empresas estatais é especialmente eficaz quando implica desnacionalização e entrada de recursos novos em moeda de liquidez internacional. Nesse caso, ela contribui, ainda que transitoriamente, para equacionar os problemas financeiros internos do setor público e, ao mesmo tempo, para o financiamento do desequilíbrio do balanço de pagamentos em conta corrente. Sinal de que talvez seja neste ponto, e não nos ganhos de eficiência ou na confiança no mercado, que se localizam as razões primordiais da ênfase atribuída à privatização está no fato de ela ter resultado, em diversos casos, na simples transformação de monopólios públicos em monopólios privados. Outro sinal reside no fato de que diversas operações ditas de privatização consistiram, em realidade, na transferência do controle acionário a empresas estatais estrangeiras (Batista, 1994:31). 
Antes de passar à análise do caso brasileiro, convém advertir que o modelo de estabilização e integração internacional acima discutido não foi aplicado de forma geral na América Latina, ainda que diversos dos seus elementos estejam presentes nas políticas econômicas de todos os países da região. Evita-se, por isso, a designação neoliberal para caracterizar as experiências discutidas neste trabalho. Por ser excessivamente genérica, tal designação oculta importantes diferenças de abordagem e desempenho entre as economias da região.

Chile e Colômbia, por exemplo, adotaram nos últimos anos políticas bastante distintas das que prevaleceram no México, na Argentina, e mais recentemente no Brasil, em especial no que se refere a política cambial, abertura financeira externa e dependência de capitais de curto prazo. No Chile e na Colômbia, por motivos que não discutirei aqui, as políticas cambiais foram mais flexíveis, voltadas em geral para a defesa da competitividade externa; além disso, em diversos períodos foram adotadas fortes restrições à entrada de capitais externos de curto prazo (5). Por isso mesmo, esses dois países escaparam basicamente incólumes às ondas de instabilidade desencadeadas pelo colapso do peso mexicano em fins de 1994.

\section{O ponto de partida do Plano Real}

Do ponto de vista fiscal e monetário, o Plano Real estava longe de oferecer garantias suficientes em 1993-94. A equipe econômica do governo reiterava constantemente a sua determinação de mudar o regime fiscal-monetário, isto é, de realizar modificações de caráter fundamental no campo das finanças públicas e da gestão da moeda, inclusive como precondição das medidas de desindexação. Mas o governo Itamar Franco era um governo fraco, já em fim de mandato, sem base parlamentar estável e que não contava com a legitimidade associada à eleição pelo voto direto. Não havia condições políticas para construir um programa de estabilização com sólidos fundamentos fiscais e monetários.

É inegável que a política fiscal de 1993 e 1994 produziu alguns resultados, como o reconhecimento da constitucionalidade da Contribuição para o Financiamento da Seguridade Social - COFINS, a instituição do Imposto Provisório sobre Movimentação Financeira - IPMF, a aprovação do chamado Fundo Social de Emergência - FSE e os avanços no combate à evasão fiscal durante a gestão de Osiris Lopes Filho na Receita Federal. Alguns desses mecanismos eram, entretanto, de natureza transitória. De qualquer forma, os ganhos obtidos em tais frentes eram neutralizados, no todo ou em parte, por despesas expressivas em certas áreas. Parte do problema residia no fato de o governo Itamar haver herdado do governo Collor enorme repressão de determinados tipos de gastos, notadamente na área da Previdência Social e na remuneração dos servidores federais.

As finanças estaduais e municipais também davam sinais de fraqueza, atribuíveis em parte a circunstâncias eleitorais. A intervenção no Banerj e especialmente no Banespa, em fins de 1994, revelaria mais claramente o grau de desordem das finanças em alguns dos principais estados da Federação. 
Ao mesmo tempo, o componente financeiro do déficit público via-se pressionado por acordos onerosos negociados pelos governos Collor e Itamar com o Clube de Paris e os bancos comerciais estrangeiros (6). Além disso, a política de juros altos, que vinha sendo utilizada para assegurar a formação das reservas internacionais necessárias à sustentação da futura âncora cambial, onerava as finanças públicas federais e as dos estados e municípios mais endividados. A esterilização do impacto monetário das operações do setor externo contribuía também para uma rápida expansão da dívida mobiliária federal. Entre dezembro de 1991 e junho de 1994, a dívida federal em títulos (exclusive papéis na carteira do Banco Central) aumentou de 2,7\% para 10,4\% do PIB (7).

Em suma, nada havia que pudesse ser apresentado, com alguma plausibilidade, como uma mudança de regime fiscal, para usar a expressão consagrada por Sargent (1986:40-47). Para aqueles que julgavam depender essa mudança fundamentalmente de emendas à Constituição, a oportunidade de ouro era o período de revisão constitucional, por rito simplificado, previsto nas Disposições Transitórias da própria Constituição (8).

Entretanto, a revisão constitucional de 1993-94 ficaria aquém das expectativas mais modestas. Do ponto de vista do programa de estabilização, a única emenda relevante foi a já mencionada aprovação do chamado Fundo Social de Emergência para o período 1994-95, na verdade um mecanismo de desvinculação de receitas (9).

No campo monetário, a situação não era melhor. Preocupado em dissipar o ceticismo resultante das inúmeras reformas monetárias fracassadas desde o Plano Cruzado, a área econômica do governo insistia em afirmar que a introdução de uma nova moeda estaria, desta vez, respaldada em uma mudança do regime monetário, vale dizer, das regras que governam a criação de moeda no país (10).

Em tese, a prometida mudança de regime monetário poderia ter tomado a forma da implantação de um sistema de conversibilidade com câmbio fixo, a exemplo do que ocorrera na Argentina em 1991. Essa alternativa tinha seus defensores na equipe econômica do governo e parece ter sido seriamente considerada (11). Outra possibilidade seria uma reforma do estatuto do Banco Central que o tornasse mais autônomo. Por motivos que não discutirei aqui, nada disso seria feito por ocasião da criação da nova moeda. A mudança nas regras de emissão limitar-se-ia à fixação de tetos para a base monetária, que tiveram importância apenas transitória, sendo revistos e depois abandonados em questão de poucos meses.

\section{Trunfos externos do Plano Real}

Não era, portanto, nos campos fiscal e monetário que o Plano Real encontrava os seus pontos de apoio. Os trunfos principais, que seriam intensamente utilizados a partir de julho de 1994, estavam localizados no setor externo da economia. 
O Brasil era, naquela altura, um dos poucos países da América Latina que se mostrava capaz de gerar superávits substanciais na balança comercial. Em 1992, o saldo comercial alcançou US\$ 15,2 bilhões, o equivalente a 43\% das exportações de mercadorias; no ano seguinte, US $\$ 13,3$ bilhões, $35 \%$ das exportações (tabela 1). Nesse período, nenhuma outra economia latino-americana estava produzindo superávits tão elevados como proporção das exportações (12).

No ano calendário imediatamente anterior à reforma monetária e cambial, o saldo da balança comercial, somado às transferências unilaterais líquidas, foi quase equivalente ao déficit na balança de serviços (tabela 1 ). O déficit em conta corrente de 1993 correspondeu, assim, a apenas $1,5 \%$ das exportações e a $0,1 \%$ do PIB em dólares estimado pelo Banco Central (13).

Até 1994 a posição brasileira em termos de balanço de pagamentos em transações correntes comparava-se muito favoravelmente com a dos demais países da América Latina. A tabela 2 permite confrontar os déficits em conta corrente registrados pelo Brasil com os déficits de quatro outros países da América Latina desde 1992. Nos anos que antecederam a crise mexicana, os déficits foram menores em países que adotaram políticas cambiais mais prudentes, como a Colômbia até 1993 e o Chile durante todo o período recente. Já na Argentina e no México, onde a taxa cambial foi sistematicamente utilizada como instrumento de combate à inflação, os déficits correntes alcançaram níveis elevadíssimos até 1994. A razão déficit em conta corrente/exportações foi de 59\% na Argentina e de 83\% no México em 1994 (tabela 2).

O melhor desempenho do balanço de pagamentos do Brasil era atribuído, em parte, ao maior realismo da política cambial brasileira que, em contraste marcado com a que se praticava no México e na Argentina, procurava estabilizar a taxa de câmbio em termos reais. Como tudo mais na economia brasileira, o preço da moeda estrangeira estava submetido ao regime de indexação; o ritmo de desvalorização da taxa nominal bilateral com o dólar era ditado, basicamente, pela elevada taxa de inflação doméstica.

Ao contrário do que ocorrera na Argentina, onde a fixação do câmbio foi antecedida por um período de forte valorização cambial, no Brasil a taxa de câmbio real permanecera relativamente estável desde a mididesvalorização de fins de 1991 até junho de 1994. Daí se concluía que o Brasil poderia absorver apreciação cambial significativa em termos reais sem causar maiores danos à posição externa da economia.

Mas o trunfo mais alardeado e que mais impressão causava era, como se sabe, o elevado nível das reservas internacionais do Banco Central, acumuladas desde fins de 1991. Em junho de 1994, as reservas no conceito de caixa chegavam a nada menos que US\$ 40,1 bilhões, dos quais cerca de 70\% haviam sido constituídos desde a posse de Fernando Henrique Cardoso como Ministro da Fazenda.

Em retrospecto, parece evidente que a acumulação de reservas fez parte das medidas preparatórias da reforma monetária e cambial. A preocupação de 
tomar precauções desse tipo refletia, presumivelmente, a percepção de que o insucesso de programas anteriores de estabilização no Brasil, notadamente do Plano Cruzado, se devera em parte a dificuldades de natureza cambial. A reforma monetária do Plano Real começaria com reservas, no conceito de caixa, equivalentes a 18 meses de importação de mercadorias (FOB), considerada a média mensal dos 12 meses imediatamente anteriores a julho de 1994 (tabela 3). Pelo mesmo critério, o Plano Cruzado havia começado com reservas correspondentes a seis meses de importação; a reforma monetária de março de 1990 (o Plano Collor I), com reservas correspondentes a três meses de importação (14).

O Plano Real estava bem suprido de reservas mesmo quando comparado aos programas mexicano e argentino, ambos conhecidos por terem sido precedidos de um período de formação de reservas. O México começara a sua estabilização com reservas de 12 meses de importação em dezembro de 1987 (15); a Argentina dispunha de reservas para 14 meses de importação às vésperas da promulgação da lei de conversibilidade (16).

Por último, em contraste com o quadro que prevalecera durante a maior parte da década de 80 e até o início dos anos 90, o Brasil dispunha agora de acesso aos mercados financeiros internacionais, graças à ampliação da liquidez internacional e à diminuição das taxas de juro para operações em dólares. Pela primeira vez em quinze anos, parecia possível realizar uma tentativa de estabilização monetária em um contexto de abundância de recursos externos. Como já foi indicado, a própria acumulação de reservas não teria sido factível na dimensão verificada sem a possibilidade de mobilizar fundos externos. A expectativa governamental era de que os déficits em conta corrente resultantes do programa de estabilização poderiam ser financiados sem maior dificuldade nos mercados internacionais.

\section{Reservas internacionais \\ e passivos externos de curto prazo}

Em retrospecto, parece claro que havia no Brasil certa tendência a superestimar os trunfos externos de que dispunha o Plano Real em meados de 1994. Nem tudo era tão sólido quanto poderia sugerir um exame superficial das contas externas brasileiras e do contexto internacional, como logo ficaria evidente pela dificuldade com que o Brasil respondeu ao impacto da crise mexicana no início de 1995. A aceitação acrítica de certas teses terminaria por contribuir para decisões temerárias em matéria de política cambial e comercial ao longo do segundo semestre de 1994, como veremos na seqüência.

Considere-se, em primeiro lugar, as decantadas reservas internacionais no Banco Central. Não se dava, em geral, suficiente atenção à natureza do estoque de liquidez internacional constituído essencialmente a partir do início de 1992. Do aumento de US\$ 32 bilhões nas reservas, entre dezembro de 1991 e junho de 1994, pouco mais de $20 \%$ haviam resultado de superávits no balanço de pagamentos em conta corrente. Em outras palavras, tratava-se no fundamental de 
reservas emprestadas $\mathrm{e}$ - o que era pior - formadas sobretudo por ingressos líquidos de investimentos de carteira (aplicações em bolsas de valores, debêntures e outros ativos financeiros) e de empréstimos de curto e médio prazos (linhas comerciais, notas, bônus etc.)

Nesse período, a maior parte dos investimentos estrangeiros recebidos pelo Brasil eram aplicações de carteira, que podem, como se sabe, sair do país de forma instantânea. Em 1992-94, 80\% do influxo líquido de recursos sob a forma de investimentos estrangeiros corresponderam a aplicações de portfólio (tabela 4).

Pelos recursos externos captados sob a forma de bônus, notas e certificados de depósitos, com prazos de quatro a seis anos, pagava-se em média taxas anuais de juro 5 a $7 \%$ acima das taxas pagas por papéis do Tesouro americano de prazo similar (17), muito superiores às taxas de juro que se pode obter com a aplicação das reservas internacionais. A acumulação de reservas financiada por empréstimos relativamente caros resultava, portanto, em ônus expressivo para a conta de serviços do balanço de pagamentos em períodos subseqüentes. Ainda mais pesado era o impacto sobre as finanças públicas, uma vez que a remuneração das reservas correspondia a fração ainda menor do custo da dívida mobiliária federal colocada para esterilizar o impacto monetário das operações cambiais.

A relativa fragilidade das reservas fica evidente quando se leva em conta os dados referentes aos passivos externos de curto prazo do país. Entre dezembro de 1991 e junho de 1994, a dívida externa de curto prazo (exclusive atrasados) dobrou, passando de US\$ 14,6 bilhões para US\$ 30 bilhões, segundo dados do Banco Central (tabela 5). Em junho de 1994, a dívida externa líquida de curto prazo - definida como a diferença entre a dívida (exclusive atrasados) e os haveres externos de bancos comerciais brasileiros - alcançava US\$ 19,9 bilhões, o equivalente a quase metade das reservas no Banco Central (tabelas 3 e 5 ).

Nessa época, segundo dados da Comissão de Valores Mobiliários - CVM, a carteira de ativos de investidores institucionais estrangeiros (Anexo IV da Resolução $1.289 / 87)$ correspondia a US\$ 13,6 bilhões, aplicados em ações (67\% do total), debêntures, derivativos, moedas de privatização e outros ativos financeiros (tabela 6). Como esses dados não cobrem a totalidade dos investimentos de portfólio, outra forma de tentar mensurar o estoque de passivos desse tipo é somar os fluxos líquidos registrados sob essa rubrica na conta de capitais do balanço de pagamentos. Se tomarmos 1988 como ponto de partida, ano em que o governo começou a remover as restrições aos investimentos externos de carteira, o ingresso líquido acumulado em junho de 1994 alcançava US\$ 14,9 bilhões (18), correspondendo a mais de um terço das reservas então existentes.

É verdade que o mercado de capitais brasileiro não comportaria saídas maciças de recursos sem perda do valor dos investimentos. Por outro lado, o risco de perda tenderia justamente a acelerar a saída de recursos em momentos de desconfiança ou incerteza.

Em suma, a maior parte das reservas internacionais tinha origem na acu- 
mulação de obrigações financeiras de curto prazo ou aplicações volatéis. A tabela 5 compara o passivo externo de curto prazo com as reservas internacionais no Banco Central. Em fins de junho de 1994, na véspera do lançamento do real, a soma da dívida de curto prazo (líquida de haveres externos de bancos comerciais) com a carteira de ativos de investidores institucionais estrangeiros (Anexo IV) chegava a US\$ 33,5 bilhões, o equivalente a $83,4 \%$ das reservas brutas no Banco Central.

No que diz respeito ao endividamento de curto prazo, a posição brasileira era, naquela altura, comparável à do México ou à da Argentina. É o que se depreende de alguns indicadores publicados pelo American Express Bank. No final de junho de 1994, a dívida de curto prazo com o sistema bancário internacional (definida de forma a incluir não só dívidas de prazo original inferior a um ano, como também os vencimentos de principal, até junho de 1995, das dívidas de médio e longo prazos) representava $55,3 \%$ do total da dívida bancária no caso do Brasil. Os percentuais correspondentes para a Argentina e o México eram $56,6 \%$ e $59,8 \%$, respectivamente, com inclusão dos tesobonos no dado mexicano (19). Naquela data, a dívida de curto prazo representava 91,3\% das importações no caso do Brasil, contra 79\% no da Argentina e 54,4\% no do México (tabela 7).

Evidentemente, não se deve inferir desses indicadores isolados que a posição global do Brasil era pior ou mesmo equivalente à dos outros dois países. Outros indicadores importantes, como por exemplo o nível de reservas, revelavam um quadro bem mais favorável ao Brasil na comparação com Argentina e México. Relativamente às importações, as reservas brasileiras eram naquele momento quase o dobro das argentinas e quase sete vezes as mexicanas (tabela 7). Além disso, a posição brasileira em conta corrente era, como vimos, muito mais forte do que a do México ou a da Argentina, países engajados há vários anos em processos de estabilização ancorados no câmbio.

De qualquer maneira, a dimensão das obrigações de curto prazo ou voláteis indicava que a garantia proporcionada pelo elevado nível das reservas brutas do Banco Central não era tão sólida quanto geralmente se admitia. A relativa fragilidade das reservas brasileiras ficaria evidente depois de dezembro de 1994, quando a onda de desconfiança produzida pelo colapso do peso mexicano provocaria abrupta diminuição das reservas e fortes abalos na condução do Plano Real.

\section{Valorização cambial anterior ao Plano Real}

Outra meia-verdade dizia respeito à posição da taxa de câmbio no início da reforma monetária. Como já mencionado, admitia-se, sem maior qualificação, que a política cambial seguida pelo Brasil até junho de 1994, de indexação do preço do dólar, criava uma margem de manobra adequada à utilização de uma âncora cambial. Destacados integrantes da equipe econômica chegaram a afirmar, mais de uma vez, que a moeda brasileira estava subvalorizada na época da introdução do real (20). 
O exame da trajetória da taxa de câmbio real nos anos anteriores à reforma monetária não parece dar suporte a essas afirmações. Ao contrário, o que vinha ocorrendo antes da criação da nova moeda era uma gradual, porém significativa, valorização da moeda nacional em termos reais.

Estatísticas publicadas pela CEPAL permitem comparar a evolução da taxa de câmbio brasileira com a de outros países latino-americanos. A tabela 8 registra a evolução do câmbio em termos efetivos (isto é, calculada com base em uma cesta de moedas) para cinco países. Convém destacar a posição registrada em 1993, ano calendário imediatamente anterior à reforma monetária brasileira e à crise do México. Tomando-se 1987 como ano-base, o índice da taxa de câmbio real efetiva, elaborado com índices de preços ao consumidor, era de 59 para o México e de 60 para a Argentina em 1993; no caso da Colômbia e do Chile, países que adotaram políticas cambiais mais prudentes nesse período, o mesmo índice situava-se em 102 e 100, respectivamente, em 1993 (tabela 8). Em outras palavras, Chile e Colômbia mantiveram taxas de câmbio estáveis em termos reais, enquanto México e Argentina acumularam valorização real do câmbio da ordem de $40 \%$ nos seis anos que antecederam o colapso do programa mexicano.

Apesar da sua tradição de indexação cambial, o Brasil estava mais próximo do México e da Argentina do que da Colômbia e do Chile no que tange à evolução do câmbio efetivo real desde fins dos anos 80. Para o Brasil, o índice era de $75 \mathrm{em} 1993$. Essa valorização acumulada de $25 \%$ refletia sobretudo o que acontecera no período 1988-1990 (tabela 8).

Alegou-se que ganhos de produtividade na indústria e em outros setores da economia teriam compensado, pelo menos em parte, os efeitos da valorização cambial sobre a competitividade internacional da economia. Os elevados superávits na balança comercial também eram apontados como argumento a favor da tese de que inexistia defasagem cambial até meados de 1994.

É possível que o primeiro argumento tivesse alguma base, embora nunca tenha sido convincentemente demonstrado que os ganhos de produtividade da economia brasileira, relativamente aos dos seus concorrentes internacionais, fossem suficientes para neutralizar os efeitos da valorização cambial sobre a competitividade das exportações e dos setores que concorrem com importações. É de se notar que, desde meados dos anos 80, as exportações brasileiras vinham perdendo participação nas exportações mundiais e nas exportações dos países em desenvolvimento. Entre 1980-85 e 1990-93, a participação do Brasil nas exportações mundiais sofreu queda significativa, caindo de $1,28 \%$ para $0,94 \%$. No mesmo período, a participação das exportações brasileiras no total exportado por países em desenvolvimento não-exportadores de petróleo diminuiu de forma ainda mais pronunciada, passando de $5,98 \%$ em $1980-85$ para $4,08 \% \mathrm{em} 1990$ 93 (tabela 9).

Quanto ao segundo argumento, cabe observar que os saldos comerciais já vinham sofrendo sensível diminuição mesmo antes de julho de 1994. Compara- 
do às exportações, o superávit da balança comercial caíra de 52\% em 1988-89 para 39\% em 1992-93. Como proporção do PIB em dólares, o saldo comercial diminuíra de $5,1 \%$ para $3,5 \%$ no mesmo período (tabela 10 ).

Era preciso levar em conta também que os saldos comerciais ainda elevados refletiam, em grande medida, o deprimido nível de atividade econômica no final dos anos 80 e início dos anos 90, época de recessão ou crescimento medíocre para a economia brasileira. O superávit estrutural, isto é, ajustado para excluir efeitos cíclicos, era muito menor do que o observado entre 1988 e 1993. A volta a nível mais normal de utilização da capacidade produtiva geraria fatalmente uma queda expressiva do saldo comercial, sobretudo se combinada com a ancoragem cambial e a aceleração do processo de liberalização comercial.

A própria experiência do Brasil nos anos 80 apontava nessa direção. A aceleração do crescimento econômico em 1980, por exemplo, conjugada com a prefixação da desvalorização cambial nominal a partir de janeiro daquele ano, contribuíra para uma significativa deterioração da conta corrente. Em 1986, durante o Plano Cruzado, a combinação de expansão da demanda com câmbio congelado desembocara em ampliação ainda mais acentuada da brecha em conta corrente (tabela 10).

A experiência recente do México e da Argentina também indicava a velocidade com que pode ser revertida uma situação aparentemente folgada no balanço de pagamentos em conta corrente. Os dois países haviam iniciado os seus programas de estabilização com superávits não apenas na balança comercial, mas mesmo em transações correntes. No ano calendário imediatamente anterior ao começo do programa, em 1987, o México registrara um superávit comercial de US\$ 8,4 bilhões e um superávit em conta corrente de US\$ 4 bilhões. No caso da Argentina, o superávit alcançara US $\$ 8,6$ bilhões na balança comercial e US\$ 1,9 bilhão em conta corrente em 1990 (21).

Logo no primeiro ano apareceram déficits significativos, resultado da ação combinada da apreciação real do câmbio, da remoção de barreiras à importação e (no caso da Argentina) da rápida recuperação da demanda agregada interna. Em 1988 a balança comercial mexicana acusou superávit bem menor, de US\$ 1,7 bilhão, com as importações crescendo de forma acentuada, $55 \%$ se comparadas com o valor registrado no ano anterior. Em conseqüência dessa drástica diminuição do saldo comercial, a conta corrente passou a acusar déficit de US\$2,4 bilhões. Na Argentina, o quadro foi semelhante em 1991: deterioração marcada da balança comercial, cujo saldo caiu para US $\$ 4,4$ bilhões, em função do explosivo crescimento das importações, $103 \%$ com relação ao ano anterior, e deterioração ainda maior do balanço de pagamentos em transações correntes, que passou a um déficit de US\$ 2,8 bilhões (22).

Do Plano Real, modelado em grande medida nas experiências supostamente exitosas desses países, não se poderia esperar algo muito diferente. Como veremos, o Brasil engajar-se-ia tardiamente, mas em compensação com muito 
afinco, na estratégia de combate à inflação com desequilíbrio externo, encetada anteriormente por México e Argentina. No início de 1994, entretanto, o Federal Reserve dos EUA começara a elevar as taxas de juro de curto prazo, fato que contribuiria de modo decisivo para estreitar a oferta de fundos para alguns países latino-americanos, notadamente o México.

O colapso do programa mexicano em dezembro de 1994 e suas repercussões devastadoras sobre a oferta de crédito externo para vários países no início de 1995 revelariam o quanto eram infundadas as expectativas, alimentadas pela equipe econômica do governo brasileiro, de que o Brasil poderia conviver tranqüilamente com déficits comerciais e forte dependência de capitais internacionais.

Mas antes de entrar na discussão dos efeitos da crise mexicana sobre o Plano Real, convém examinar, em linhas gerais, a forma como o Brasil realizou a sua reforma monetária e cambial a partir de julho de 1994.

\section{Âncora monetária e valorização cambial}

Em contraste com o que ocorrera nos casos do México em 1988 e da Argentina a partir de abril de 1991, a reforma brasileira de julho de 1994 foi seguida de uma valorização acentuada e inesperada da taxa de câmbio nominal. Entre fins de junho e fins de setembro, a taxa real/dólar sofreu redução de 15\% (23), contrariando a expectativa mais comum de que o governo fixaria a taxa nominal de câmbio a partir de julho.

Esse comportamento inicial da taxa de câmbio foi objeto de intensa controvérsia no Brasil e é considerado por muitos observadores como um dos equívocos fundamentais do Plano Real. Na época, a equipe econômica do governo limitava-se a sustentar, algo falaciosamente, que a queda do dólar era resultado das "forças de mercado", posto que o Banco Central se retirara do mercado de câmbio. Para tentar entender o que aconteceu de julho de $1994 \mathrm{em}$ diante é necessário, contudo, situar o movimento do câmbio no contexto econômico e político mais amplo.

O governo sabia, naturalmente, que a estabilização monetária, realizada em condições de inflação crônica e muito alta, tenderia a produzir de modo automático expansão da demanda, especialmente de consumo, pelo menos na fase inicial do programa. Essa expectativa amparava-se em diversos fatores, entre os quais se destacavam a queda drástica do chamado imposto inflacionário (e conseqüente transferência de recursos para setores de baixa renda, com alta propensão marginal a consumir) e o reaparecimento do crédito a prazos mais longos em função do surgimento de um padrão monetário mais estável.

No caso brasileiro, segundo a análise dos economistas do governo, havia ainda uma circunstância peculiar: ao contrário do que costuma ocorrer em processos de estabilização em condições de hiperinflação ou inflação muito alta, o efeito Olivera-Tanzi seria sobrepujado pelo aumento dos gastos públicos reais 
associado à queda da inflação (Bacha, 1994). A hipótese - que ficou conhecida como efeito Bacha - era de que sendo os gastos públicos, em média, menos indexados do que as receitas públicas, o déficit fiscal real aumentaria com a estabilização, reforçando o efeito expansivo da ampliação do consumo e de outros componentes do gasto privado.

Dentro de certos limites, a expansão da demanda era evidentemente muito bem-vinda, dado que ocorreria, não por acaso, em uma fase decisiva do processo eleitoral em curso. Por outro lado, a experiência latino-americana e do próprio Brasil, notadamente com o Plano Cruzado, mostrava que a expansão produzida endogenamente pela estabilização se convertera em uma das causas fundamentais do naufrágio de diversas tentativas de combate à inflação.

Tornava-se necessário, portanto, adotar providências para contê-la. Uma das alternativas seria o ajuste fiscal. Se acionada a tempo, a política fiscal poderia desempenhar um papel compensatório, contra-arrestando a expansão endógena do gasto privado. Como a política fiscal é notoriamente pouco flexível no curto prazo e está sujeita a um processo decisório lento, as medidas teriam de ser tomadas com alguma antecedência para que pudessem ter o efeito compensatório pretendido. Essa seria uma maneira de justificar a seqüência de fases estabelecida para o Plano Real em fins de 1993.

O programa de estabilização desdobrava-se em três fases: a fase I, anunciada em fins de 1993, consistia de um ajuste fiscal de caráter preparatório; a fase II viria a ser implementada a partir de março de 1994 com a introdução da URV; e a fase III seria iniciada em julho com a criação do real. A fase I deveria, em tese, lançar as bases ou os fundamentos fiscais da desindexação e da reforma monetária.

A seqüência escolhida pelo governo brasileiro refletia também a preocupação de influir sobre as expectativas dos agentes econômicos. Mesmo que não houvesse grande preocupação com a necessidade de neutralizar em parte o impacto da fase III sobre a demanda, ou não se acreditasse que ele seria significativo o suficiente para recomendar uma compensação pelo lado fiscal, a seqüência anunciada refletia a preocupação em conquistar reputação ou credibilidade. Essa segunda interpretação encontra mais amparo no discurso e nos documentos oficiais da época (24).

A preocupação em conquistar credibilidade fiscal, sempre presente nas tentativas de combate à inflação, era vista como especialmente importante no caso brasileiro, uma vez que se consolidara, entre os agentes econômicos, os formadores de opinião, na grande imprensa e nos meios de comunicação em geral, a convicção de que os programas anteriores de desindexação e reforma monetária haviam fracassado fundamentalmente por falta de ajuste duradouro das contas públicas.

Por esse ângulo, o ajuste fiscal prévio ou a mudança prévia de regime fiscal desempenharia o papel de contribuir para a reversão das expectativas inflacionárias, ao sinalizar que o governo não mais se financiaria por meios inflacionários. 
Em outras palavras, o governo procurava persuadir os agentes econômicos de que, desta vez, não deixaria para depois a parte politicamente mais difícil do processo de estabilização. Repetia-se ad nauseam que a desindexacão e a troca de moeda não seriam realizadas sem garantir antecipadamente uma posição fiscal sólida.

Como acontece tantas vezes, na passagem da teoria à prática perdeu-se grande parte da primeira. Vimos que a política fiscal de 1993-94, a despeito de avanços localizados, não continha elementos que permitissem considerá-la uma mudança de caráter fundamental na situação das finanças do governo.

Ademais, abandonada a opção por uma regressão a um modelo monetário semelhante ao antigo padrão-ouro ou ao currency board das colônias inglesas, caminho seguido pela Argentina na sua famosa lei de conversibilidade, o governo brasileiro encontrava dificuldades para caracterizar a reforma monetária como uma mudança de regime monetário. Às vésperas da reforma de julho, havia motivos para temer que a nova moeda fosse recebida como mais uma jogada de fôlego curto e imediatismo eleitoral.

Descartada a dolarização à moda argentina, como compensar no campo monetário a fragilidade dos fundamentos fiscais? Admitindo-se que se atribuísse papel decisivo às expectativas de inflação, formadas racionalmente à luz do caráter percebido do regime de política econômica, ainda haveria a possibilidade de atuar sobre as expectativas por meio da imposição de algum tipo de camisa-deforça razoavelmente crível no campo monetário?

A solução encontrada foi curiosa e inesperada: uma regressão monetária, porém não ao padrão-ouro ou ao modelo monetário das antigas colônias inglesas. O que se tentou durante alguns meses foi seguir um modelo monetarista ou quase-monetarista, no qual a garantia da confiabilidade do novo padrão monetário residiria na fixação de tetos trimestrais de expansão monetária, incluídos na medida provisória que criou o real (25). Estabeleceu-se assim que a emissão de reais não poderia ultrapassar $\mathrm{R} \$ 7,5$ bilhões até 30 de setembro de 1994, R \$ 8,5 bilhões até 31 de dezembro de 1994 e R\$ 9,5 bilhões até março de 1995 (26).

Ora, esse tipo de regime monetário já havia sido testado e rejeitado na maioria dos países desenvolvidos. Desde os anos 70, e particularmente no início dos 80 , a experiência desses países vinha comprovando a ineficácia da ancoragem monetária à la Milton Friedman e, em particular, o caráter ilusório da suposição monetarista de que a demanda real por moeda poderia ser considerada uma função estável de algumas variáveis facilmente identifícáveis (27). Se isso era verdadeiro em países de economias e moedas relativamente estáveis, como aplicar metas monetárias a uma economia como a brasileira, em processo de transição de uma inflação altíssima para taxas de 2 ou $3 \%$ ao mês?

Naturalmente, a súbita conversão à ancoragem monetária era, em certa medida, parte da fachada ou do marketing do programa de estabilização. A insistência na importância dos fundamentos fiscais e monetários deveria ser vista, 
pelo menos em parte, como uma homenagem retórica à sabedoria convencional. Afinal, como desconhecer àquela altura as evidências, recolhidas da história recente e remota, de que nas grandes estabilizações os fundamentos são construídos, paradoxalmente, ao longo do processo, funcionando mais para consolidar do que para dar início à queda da inflação? Hans Luther, o ministro das Finanças que conduziu o programa de estabilização alemão iniciado em 1923 expressou esse ponto numa passagem famosa. No caso alemão, escreveu, fora necessário “começar a construir a casa pelo teto" (Luther, 1928:177-178).

No Brasil de 1994, ainda que a metáfora de Luther talvez não seja inteiramente apropriada como descrição do que aconteceu, a ninguém ocorreria atribuir o colapso da inflação a partir de julho a uma súbita reversão das expectativas provocada pelo compromisso legal com metas monetárias anunciadas como inamovíveis, tanto mais que o instituto da medida provisória, especialmente no caso de sucessivas reedições mensais, transformava qualquer garantia desse tipo em uma "camisa-de-força com zíper na frente", para usar uma expressão cunhada por Mario Henrique Simonsen em outro contexto.

$\mathrm{Na}$ verdade, a queda da inflação foi produto da combinação de ampla operação de desindexação, do congelamento dos preços e tarifas públicas e do uso sistemático de munição acumulada no setor externo. A transformação da URV em moeda plena removeu, de forma engenhosa, grande parte do componente inercial da taxa de inflação. Ao mesmo tempo, como veremos mais à frente, a política cambial e a política de comércio exterior foram colocadas à serviço dos propósitos de curto prazo da estabilização monetária. A âncora monetária e as constantes profissões de adesão ao fundamentalismo fiscal-monetário entravam aí um pouco como Pilatos no Credo (28).

Isso não significa que a âncora monetária tenha tido função meramente decorativa ou psicológica. Compromissos com determinadas metas, ainda que assumidos sem convicção plena, terminam por inibir de alguma maneira a condução da política econômica.

No Brasil, o debate econômico e mesmo a política econômica sofriam (e ainda sofrem) do artificialismo do debate macroeconômico internacional, especialmente desde os anos 70, e da influência de discussões de grande prestígio intelectual, porém algo esotéricas, sobre temas como regimes e estratégias de política econômica, formação de expectativas, credibilidade etc. Nem sempre é fácil, por exemplo, estabelecer ex ante se determinada tentativa de estabilização comanda credibilidade ou constitui mudança de regime. Isso não impede, entretanto, que os insucessos sejam sumariamente atribuídos, ex post factum, à insuficiência dos fundamentos e à falta de credibilidade do programa. Conceitos centrais à teoria macroeconômica e à sua aplicação prática revestem-se, muitas vezes, de caráter escorregadio e indeterminado. Grande parte das proposições aceitas como verdadeiras não passaria facilmente pelo crivo do critério de Popper, segundo o qual uma hipótese só tem caráter científico quando formulada de tal maneira a que possa ser objeto de refutação ou falsificação (29). 
Além disso, como costuma acontecer, o desgaste experimentado nos países desenvolvidos ao longo dos anos 80 pelo monetarismo friedmaniano e seus sucessores da escola de expectativas racionais não fora devidamente registrado pelo debate econômico brasileiro, que continuava fortemente marcado pela repetição irrefletida das modas e dogmas dos anos 70 e 80.

Esse caldo de cultura intelectual teria alguma influência sobre a condução prática da política econômica a partir de julho.

Como vimos, uma preocupação prática fundamental era com o já referido impacto expansivo da estabilização e o risco de que o crescimento da demanda, especialmente de bens de consumo, pudesse fugir ao controle da Fazenda e do Banco Central. Tal impacto, como hoje sabemos, seria mais intenso do que geralmente se imaginava. Dado que nada de fundamental havia sido feito pelo lado fiscal, a alternativa de que dispunha o governo era recorrer à elevação das taxas de juro reais.

Na presença de mobilidade internacional de capitais, o resultado foi um aumento do já elevado superávit na conta de capitais e excesso de oferta de divisas no mercado de câmbio. Se o Banco Central absorvesse a oferta excedente, acumulando reservas cambiais adicionais, poderia colocar em risco a consecução das metas monetárias, suposto sustentáculo da reforma monetária. Consistentemente com a opção pela âncora monetária, o Banco Central retirou-se do mercado de câmbio, permitindo que o excesso de oferta de divisas ocasionado pela sua política de juros se refletisse em queda do câmbio nominal. A adesão do Brasil a um regime de flutuação cambial duraria até o final de setembro (30).

A recomposição da demanda real por moeda acabaria sendo mais rápida do que previra o governo na época da introdução do real. Os tetos de expansão da base monetária passaram então por sucessivas revisões e redefinições. Na prática, acabaram sendo relegados a segundo plano, alguns meses mais tarde, sem que isso tivesse impacto adverso perceptível sobre o andamento do programa de estabilização.

\section{O quadro político-eleitoral em 1994}

A idéia de que a problemática valorização cambial possa ser vista como mero subproduto da âncora monetária não parece, entretanto, inteiramente convincente. Não teria sido possível evitar a valorização cambial com a imposição de restrições à entrada de capitais de curto prazo? (31) Se a intenção inicial do governo era garantir o cumprimento formal das metas de expansão da base monetária, o Banco Central não poderia ter continuado a neutralizar com a colocação de títulos públicos o impacto monetário das suas intervenções no mercado cambial? É claro que essas alternativas têm as suas limitações e custos em termos econômicos, mas teriam certamente sido capazes de evitar a queda da taxa de câmbio.

Não se deve perder de vista que a valorização nominal do câmbio era bastante 
conveniente do ponto de vista eleitoral. Como se sabe, a criação do real obedecera a um timing essencialmente político, tendo sido realizada a três meses do primeiro turno das eleições presidenciais. Recorde-se que Luiz Inácio Lula da Silva, do Partido dos Trabalhadores, liderava as pesquisas de intenção de voto por larga margem até junho. Fernando Henrique Cardoso, ex-ministro da Fazenda, apoiado pelo governo e identificado como artífice do programa de estabilização, tinha na nova moeda a sua principal arma.

Em retrospecto, pode-se até sustentar que a valorização nominal do câmbio não era indispensável do ponto de vista eleitoral. Teria sido provavelmente possível produzir uma queda abrupta da taxa de inflação e um aumento do consumo, a partir de julho, sem recorrer a esse artifício. A desindexação coordenada de forma inteligente pela URV, combinada com certa estabilização nominal do câmbio e o congelamento temporário de preços e tarifas públicas, não teria sido suficiente para garantir certa estabilidade inicial da nova moeda?

Contudo, a impressão retrospectiva pode ser enganosa. Não poderia haver dúvidas quanto ao fato de que a estabilização monetária, especialmente se associada a uma reativação da economia, teria impacto sobre as intenções de voto. A própria experiência política recente da Argentina, do México e da Bolívia mostrava de forma clara o valor social e político da estabilização em sociedades submetidas a fortes processos inflacionários.

Mesmo assim, por volta de maio/junho de 1994, não havia como avaliar com precisão a reação do eleitorado, ainda que bombardeado por maciça propaganda, ao lançamento da nova moeda. Com que grau de confiança seria recebida a nova moeda por um eleitorado já calejado por tantas reformas monetárias fracassadas desde 1986?

Nesse contexto de incerteza, e dada a preocupação de derrotar o candidato da esquerda, rejeitado pelo establishment político e econômico, não era melhor pecar por excesso?

A valorização nominal teria dupla função naquela conjuntura pré-eleitoral: contribuir para acelerar a queda da inflação na reta final para o primeiro turno; e, em especial, fornecer uma espécie de bordão ao candidato do governo, que passaria a repetir insistentemente que o real "valia mais do que o dólar".

Seja qual for a interpretação mais adequada para a inesperada decisão de permitir uma valorização cambial de julho em diante, o fato é que a etapa inicial do Plano Real, até a eclosão da crise mexicana em dezembro de 1994, consistiu na utilização intensa dos trunfos de que dispunha o governo na área externa. Depois da valorização de $15 \%$ em termos nominais, a partir de outubro a taxa de câmbio permaneceu estabilizada dentro de uma banda estreita, de caráter informal, entre 83 e 86 centavos de real por dólar. Como a taxa de inflação residual em reais era muito maior do que a taxa de inflação nos EUA, o resultado foi uma fenomenal valorização real da taxa bilateral com dólar, de 30\% em apenas seis meses, quando se consideram índices de preços ao consumidor (tabela 11). Uma 
cesta de moedas, com ponderações baseadas na participação dos dez principais parceiros comerciais nas pautas de exportação e importação do Brasil, também indica uma valorização real de $30 \%$ nesse período (32). Veremos que essa maxivalorização cambial está na raiz de grande parte das dificuldades macroeconômicas enfrentadas pelo Brasil nos dois anos seguintes.

\section{O conceito de taxa de câmbio real em perspectiva histórica}

Antes de passar à discussão dos efeitos da política cambial do Plano Real, convém abrir um parêntese para uma breve digressão de caráter conceitual e histórico. Mesmo um conceito aparentemente simples como o de taxa de câmbio real dá margem a debates infindáveis, particularmente em períodos nos quais o câmbio é utilizado como âncora nominal.

O Plano Real não foge a essa regra. Tem havido grande controvérsia a respeito da extensão da valorização acumulada desde meados de 1994. Indicadores como os que foram utilizados acima, calculados com base em índices de preços ao consumidor, são contestados por diversos analistas (33). Argumentase que as estimativas do efeito da política cambial sobre a competitividade internacional da economia não devem ser distorcidas pelo uso de deflatores como os índices ao consumidor, muito influenciados por preços que não têm relação com os custos de produção, tais como aluguéis, serviços pessoais e mensalidades escolares.

Sugere-se que os índices agregados relevantes seriam os de preços no atacado, que supostamente refletiriam melhor a evolução dos custos de produção (34). Por esse critério, a valorização cambial acumulada desde 1994 é bem inferior à que resulta de cálculos baseados em índices de preços ao consumidor, como se vê na tabela 11 . A razão é que a inflação no atacado têm ficado significativamente abaixo da inflação dos preços ao consumidor (35).

Embora aparentemente plausível, e até intuitivo, o argumento não se sustenta. O problema está no fato de que os índices de preços no atacado são fortemente influenciados pelos preços de produtos comerciáveis internacionalmente, os chamados tradeables. Ora, programas de estabilização como o Plano Real, o Plano Cavallo ou o programa mexicano de 1988-94 envolvem, justamente, o uso da estabilização do câmbio nominal e da liberalização comercial para estancar o crescimento dos preços dos tradeables.

Nesse contexto, utilizar índices de preços no atacado para calcular a taxa de câmbio real constitui uma espécie de petição de princípio. A âncora cambial é aplicada para estabilizar os preços em reais dos tradeables e, depois, índices compostos em grande medida por esse tipo de produto são aplicados para argumentar que a valorização cambial não é significativa... É difícil encontrar melhor exemplo de sofisma baseado em argumento circular.

$\mathrm{Na}$ verdade, essa discussão é bastante antiga. Formados em geral dentro 
do paradigma acadêmico norte-americano, os economistas desenvolveram aguda cliofobia, uma aversão à história em geral, e até à história da sua disciplina. Assim, os mesmos debates se reproduzem diversas vezes, sem que os participantes se dêem conta de que estão regurgitando antigos argumentos e dilemas.

A questão da escolha do tipo de índice de preços relevante para deflacionar a taxa de câmbio nominal foi objeto de intensa divergência entre Keynes e os defensores da volta da Inglaterra ao padrão-ouro na década de 20. Keynes chegou a afirmar que o governo britânico não teria tomado a decisão de voltar ao padrão-ouro em 1925, restabelecendo a paridade de pré-guerra entre a libra esterlina e o ouro, se não tivesse se firmado o hábito de considerar índices no atacado como indicadores satisfatórios do poder de compra geral da moeda (36). Naquela época, observou ele, o Tesouro britânico e o Banco da Inglaterra foram levados à falsa conclusão de que, como o índice de preços no atacado, que era quase um índice de tradeables, estava se ajustando rapidamente à valorização nominal da libra, o mesmo seria verdadeiro dos preços em geral (37).

Em conseqüência, a Inglaterra acabou prisioneira de um câmbio sobrevalorizado e submetida às tensões econômicas, sociais e políticas decorrentes da tentativa, afinal frustada, de forçar a compressão dos salários e demais custos nominais. O Ministro da Fazenda responsável pela decisão de 1925, ninguém menos que Winston Churchill, diria mais tarde que esse foi o maior erro de sua vida (Buchanan et al., 1991:109).

Não é por acaso que a Argentina, tendo se amarrado em 1991 a um regime monetário extraordinariamente rígido, muito semelhante ao padrão-ouro, sofra atualmente vicissitudes análogas às que a Inglaterra sofreu entre 1925 e o abandono do padrão-ouro em 1931 (38). Já o Brasil, que não foi tão longe quanto a Argentina em matéria de compromissos no campo cambial e monetário, não precisaria afundar nos mesmos dilemas. Nem tem porque alimentar as mesmas confusões conceituais que contribuíram para que a Inglaterra convivesse continuamente com taxas elevadas de desemprego vários anos antes da Grande Depressão dos anos 30. Não obstante, veremos mais à frente que o Brasil corre o risco de chegar, por outra via, a uma situação macroeconômica semelhante à da Argentina

Do ponto de vista macroeconômico, os índices de preços ao consumidor são, entre os índices gerais normalmente disponíveis, aqueles que devem ser usados para deflacionar a taxa de câmbio, ainda que incluam, com peso expressivo, preços de bens e serviços não-diretamente relacionados à formação dos custos de produção dos setores exportadores ou sujeitos à concorrência com importações. A razão é evidente: o comportamento desses preços afeta indiretamente a competitividade internacional, na medida em que influencia o custo de vida e, portanto, os salários nominais, mesmo que estes não estejam formalmente indexados.

Outro indicador agregado que também permite avaliar os efeitos da política cambial sobre a competividade é, justamente, a relação câmbio-salário. A 
tabela 12 apresenta a relação entre taxa nominal de câmbio com o dólar e os salários nominais na indústria brasileira, com base em dados coletados pela Confederação Nacional da Indústria. Comparando as tabelas 11 e 12 , pode-se observar que a queda na relação câmbio-salário industrial desde junho de 1994 é aproximadamente equivalente à queda do índice da taxa real de câmbio, calculado com base em índices de preços ao consumidor.

\section{Desequilíbrios externos do Plano Real}

A maxivalorização cambial do segundo semestre de 1994 veio acompanhada de aceleração da política de abertura do mercado interno às importações. A intenção do governo brasileiro era evidente: submeter os formadores de preços a uma pressão sem precedentes em termos de competição externa, inundando o mercado interno com produtos importados. $\mathrm{O}$ balanço de pagamentos em conta corrente, antes protegido pela combinação de câmbio indexado e barreiras à importação, passou a ser deliberadamente sacrificado em nome do combate à inflação. Recorreu-se até mesmo à tributação das exportações de produtos com preços em alta no mercado internacional.

O caráter deliberado dessa política era confirmado pelas manifestações da equipe econômica do governo. Repetia-se insistentemente que o país deveria estar preparado para conviver com déficits comerciais por um longo período.

Dada a estrutura do balanço de pagamentos do Brasil em conta corrente, que se caracteriza por déficits elevados na balança de serviços, a disposição de acumular déficits comerciais só podia estar baseada em grande confiança na estabilidade dos mercados financeiros internacionais, em especial, na capacidade brasileira de continuar refinanciando os seus passivos externos de curto prazo e atraindo um volume expressivo de capitais externos.

Tratava-se de aposta temerária, para dizer o mínimo. Como justificar tal confiança num país que mal curara as feridas do ciclo anterior de endividamento externo? Sem ter digerido as seqüelas da longa crise da dívida externa nos anos 80 , que interrompera de forma traumática o seu desenvolvimento por mais de uma década, o Brasil estava sendo lançado em nova fase de acumulação de desequilíbrios externos e obrigações com o exterior.

O Plano Real acabaria gerando, em prazo extraordinariamente curto, um desequilíbrio no balanço de pagamentos em conta corrente comparável aos que o Brasil experimentara nos anos imediatamente anteriores à crise da dívida dos anos 80. O mais grave é que esse desequilíbrio coincidiria com a turbulência desencadeada pelo colapso do programa econômico mexicano, combinação essa que constituiria grave ameaça à sobrevivência do Plano Real nos primeiros meses de 1995.

$\mathrm{Na}$ verdade, os sinais da tempestade eram perceptíveis desde o início de 1994. A já mencionada alta das taxas de juro nos EUA, embora gradativa, tivera 
repercussões quase imediatas sobre a posição externa do México, que vinha acumulando gigantescos déficits externos há vários anos e cuja economia se tornara refém dos fluxos especulativos que permitiam financiá-los. A retração da oferta de fundos externos e a pressão sobre o peso mexicano foram acentuadas pela deterioração do quadro político interno, resultante de eventos como a revolta armada em Chiapas e o assassinato do candidato oficial à Presidência da República (39).

Nesse contexto, não é fácil justificar a ligeireza com que o governo brasileiro apostava na estabilidade do cenário internacional, e em especial na solidez da situação mexicana. Afinal, experiências anteriores, particularmente a crise financeira internacional de 1982, desencadeada a partir do colapso do México, sugeriam que o Brasil não escaparia ileso de uma eventual crise cambial mexicana, especialmente se adotasse um modelo de estabilização que viesse a ser percebido como semelhante ao daquele país.

Mas a avaliação predominante no Brasil era de uma complacência extraordinária. Até fins de 1994, poucos se dispunham a reconhecer a imensa vulnerabilidade externa dos programas mexicano e argentino. Ao contrário, esses países eram insistentemente apontados, tanto aqui como no exterior, como exemplos para o Brasil.

Foi preciso um terremoto financeiro de proporções hemisféricas, ou até globais, para que se propagasse no Brasil a lição - afinal bastante trivial - de que não é recomendável acumular déficits elevados em conta corrente financiados com hot money. Muitos dos que se apressaram a enunciar trivialidades como essa estavam entre aqueles que vinham se esmerando em destacar as virtudes do modelo mexicano, em subserviente adesão aos "consensos" alimentados pelo governo norte-americano, pelas entidades multilaterais sediadas em Washington, por Wall Street e adjacências. A grande maioria dos formadores de opinião no Brasil fizeram esse papel desde o final dos anos 80. Ajudavam assim a criar o clima intelectual que contribuiu para levar o governo brasileiro a permitir a imprudente queda do câmbio nominal, combinada com uma agressiva abertura às importações.

A deterioração da balança comercial brasileira ocorreu com velocidade fulminante e talvez tenha surpreendido até mesmo os mais ardorosos defensores do valor estratégico dos déficits externos. Já a partir de novembro de 1994 a balança comercial começou a registrar déficits vultosos. Em questão de apenas cinco meses, o saldo comercial passou de um superávit mensal médio de US\$ 1,3 bilhão, observado no trimestre imediatamente anterior à reforma monetária e cambial, para um déficit de US\$ 409 milhões em novembro e de US\$ 809 milhões em dezembro, em conseqüência do crescimento explosivo das importações (40).

No primeiro semestre de 1995 o Brasil registraria uma deterioração marcada das contas externas, que pode ser atribuída apenas em parte à crise mexicana. A tabela 13 apresenta os principais componentes do balanço de pagamentos no primeiro semestre de 1995 e permite compará-los com os resultados de igual período do ano anterior. 
A modificação mais drástica ocorreu na balança comercial, que passou de um superávit de quase US\$ 7 bilhões no primeiro semestre de 1994 para um déficit de mais de US\$ 4 bilhões no primeiro semestre de 1995. A diminuição de US\$ 11 bilhões no saldo comercial, em questão de apenas um ano, não resultou de decréscimo das exportações, que continuaram crescendo moderadamente, mas da expansão excepcional das importações, que quase dobraram nesse período. Para encontrar um surto de magnitude comparável nas despesas com importações, teríamos de remontar a 1974, ano em que as importações brasileiras duplicaram. A diferença, naturalmente, é que naquele ano o crescimento das importações decorreu, em grande medida, da quadruplicação do preço do petróleo em dólares, ao passo que em 1994-95 o aumento resultou essencialmente de fatores internos.

Também significativa foi a deterioração da balança de serviços, cujo déficit passou de US\$ 6,6 bilhões no primeiro semestre de 1994 para US\$ 9,7 bilhões em igual período de 1995. Essa deterioração refletiu, sobretudo, o aumento das despesas de juros, das remessas de lucros e das despesas com viagens internacionais (tabela 13). O saldo em conta corrente passou, assim, de um superávit de US\$ 1,4 bilhão na primeira metade de 1994 para um déficit de US\$ 11,9 bilhões na primeira de 1995 .

O déficit em conta corrente do primeiro semestre de 1995 correspondeu a $55 \%$ das exportações de mercadorias e a $4,2 \%$ do PIB estimado pelo Banco Central (41). Recorde-se que nos casos da Argentina e do México o déficit corrente representara, em 1994, o equivalente a, respectivamente, $59 \%$ e $83 \%$ das exportações (tabela 2). Vejam o que isto significa: o Brasil conseguira a proeza de acumular, já no segundo semestre da sua reforma monetária e cambial, um desequilíbrio externo em conta corrente que, como proporção das exportações, era equivalente a quase dois terços do desastroso desequilíbrio gestado pelo México ao longo de sete anos de estabilização com âncora cambial!

O desequilíbrio externo produzido nessa primeira fase do Plano Real também se aproximava perigosamente dos níveis observados nos anos que antecederam a crise da dívida externa dos anos 80. Entre 1978 e 1982, o déficit em conta corrente no balanço de pagamentos do Brasil correspondera a $62,4 \%$ das exportações e a $4,7 \%$ do PIB, em média (tabela 10). Assim, a economia brasileira, que ainda lutava para desvencilhar-se das conseqüências de uma longa crise de endividamento era levada a engajar-se, de forma intensa, em nova etapa de acumulação de passivos externos, endividando-se num ritmo comparável ao que a levara ao estrangulamento cambial do início da década passada.

As causas da deterioração de mais de US\$ 13 bilhões na posição do balanço de pagamentos em conta corrente foram essencialmente internas. A combinação de maxivalorização cambial com liberalização das importações, num quadro de expansão da demanda interna, não poderia ter outro resultado. Tanto mais que a abertura comercial não fora devidamente preparada. O governo não implantara, 
por exemplo, mecanismos anti-dumping e contra a concorrência desleal e nem dispunha de instrumentos adequados de controle dos preços praticados no comércio exterior. O sistema tributário também não fora adaptado à abertura da economia e continuava dependente de tributos que discriminavam o produtor nacional na competição com o estrangeiro, no exterior e no mercado doméstico. Além disso, o elevado custo do crédito interno prejudicava a competitividade das empresas nacionais, especialmente daquelas com pouco ou nenhum acesso ao crédito em moeda estrangeira.

Até março de 1995 as empresas nacionais beneficiaram-se, contudo, de um fenomenal crescimento das vendas internas, graças à expansão da demanda agregada, particularmente de consumo, induzida endogenamente pelo programa de estabilização. Entre julho de 1994 e março de 1995, o PIB expandiu-se a taxas excepcionalmente elevadas. Relativamente ao trimestre imediatamente anterior, o PIB dessazonalizado cresceu $3,4 \%$ no terceiro trimestre de $1994,3,5 \%$ no quarto trimestre e $2,8 \%$ no primeiro de 1995 . Nesses nove meses, a economia cresceu, portanto, a uma taxa anualizada de nada menos que $13,6 \%$, segundo dados do IBGE (42).

Esse forte aquecimento da economia pode ser atribuído, em parte, à já referida debilidade do ajuste fiscal que, contrariando as promessas do governo, não tivera impacto compensatório perceptível sobre a demanda. Além disso, o calendário eleitoral contribuiu provavelmente para que o governo adiasse para depois das eleições presidenciais as medidas de controle da expansão do crédito interno. Só em outubro o Banco Central anunciaria o primeiro conjunto de decisões voltadas para a restrição do crédito interno (43).

Nesse período, o Plano Real produziu a combinação extraordinária de crescimento rápido com inflação em queda. Medida pelo IPC da Fipe, por exemplo, a inflação caiu de $5.167 \%$ nos 12 meses até junho de 1994 para 32\% ao ano nos nove meses subseqüentes (44), resultado que se compara favoravelmente com os alcançados na fase inicial dos programas mexicano e argentino. Nos primeiros nove meses do Plano Cavallo, de abril a dezembro de 1991, a inflação anualizada fora de $29 \%$, quando medida pela variação de um índice de preços ao consumidor (45). No caso do programa mexicano, a inflação dos preços ao consumidor alcançara níveis sensivelmente mais altos nos primeiros nove meses, 65\% a.a. de janeiro a setembro de 1988 (46).

Evidentemente, só foi possível conciliar a forte expansão da demanda com sucesso na redução da inflação porque havia condições de assegurar expansão correspondente da oferta agregada. A elasticidade da oferta interna refletia a capacidade ociosa acumulada durante vários anos de recessão ou crescimento medíocre da economia. Além disso, até a eclosão da crise mexicana, as condições de balanço de pagamentos permitiram uma forte expansão da oferta externa, à custa da já comentada brutal deterioração do balanço de pagamentos em conta corrente. 
Depois do colapso do peso mexicano, contudo, o superávit na conta de capitais do balanço de pagamentos do Brasil caiu de forma drástica (tabela 13). A combinação de um acentuado déficit corrente com a contração abrupta da oferta de capitais externos levou então a rápida diminuição das reservas no Banco Central, que passaram de US\$39,5 bilhões em fins de novembro de 1994, logo antes do choque mexicano, para US\$29,9 em fins de abril de 1995, uma queda de quase $25 \%$ em apenas cinco meses (tabela 3 ).

Note-se que a perda ocorrida nesses cinco meses foi superior ao valor total das reservas existentes na época do lançamento do Plano Cruzado ou de qualquer outra tentativa posterior de combate à inflação. Sem as reservas acumuladas até junho de 1994, o Plano Real dificilmente teria sobrevivido às turbulências produzidas pela crise mexicana.

A diminuição das reservas chegou a colocar em risco o programa de estabilização e obrigaria o governo brasileiro a corrigir os rumos da sua política econômica, como veremos na seqüência.

\section{Recessão como mecanismo de ajuste das contas externas}

Era bastante clara a natureza do dilema com que se defrontava o governo Fernando Henrique Cardoso no início de 1995. Por um lado, o Plano Real trouxera ganhos expressivos em termos de redução da inflação. Por outro, resultara em desequilíbrio externo insustentável. As repercussões internacionais do colapso do programa mexicano evidenciavam os riscos associados ao tipo de política econômica praticada no Brasil a partir do segundo semestre de 1994.

O desafio era corrigir o desequilíbrio externo sem retroceder no combate à inflação. Evidentemente, o problema residia no fato de a queda da inflação ter resultado, em grande parte, de medidas responsáveis pela ampliação do déficit comercial e do déficit em conta corrente. A tentativa de combater o desequilíbrio externo com correção cambial e reversão da abertura comercial provocaria fatalmente alguma pressão inflacionária e poderia levar à reindexação da economia.

Esse era um risco que o governo recém-empossado desejava evitar a todo o custo. Afinal, o sucesso inicial no combate à inflação tinha sido o grande responsável pela vitória de Fernando Henrique Cardoso, já no primeiro turno das eleições presidenciais, e era indubitavelmente o grande trunfo político do novo governo. Permitir a volta da inflação significaria quebrar o compromisso fundamental assumido com o eleitorado e provocaria um enfraquecimento talvez irreversível do governo. A experiência do governo Sarney, que nunca conseguira recuperar-se do insucesso do Plano Cruzado, estava certamente viva na memória de todos.

Dada a dramática deterioração do balanço de pagamentos nos primeiros meses de 1995, não havia a opção de simplesmente postergar o enfrentamento 
do problema externo. Nesse contexto, era de se prever que o governo optasse por utilizar instrumentos de política econômica que permitissem conciliar o ajuste das contas externas com a preservação de taxas reduzidas de inflação.

Num primeiro momento, o Banco Central poderia naturalmente utilizar as suas reservas internacionais em defesa da taxa de câmbio. Foi o que se fez até abril. Mas essa era uma resposta de fôlego curto. A partir de março, o governo partiria para uma política mais agressiva de contenção da demanda agregada e de atração de capitais externos de curto prazo, única forma de reequilibrar as contas externas sem colocar em risco a incipiente estabilização monetária. A retração da demanda, além de diminuir o déficit em conta corrente, poderia contribuir para atenuar a alta dos preços dos bens e serviços não-comerciáveis internacionalmente, que vinham constituindo o principal fator de pressão sobre as taxas de inflação desde julho de 1994.

Isso não significa que as políticas cambial e comercial tenham ficado reduzidas a uma completa inércia. Depois de algumas hesitações, o governo acabaria se decidindo por uma reversão parcial da política de liberalização comercial, aumentando, em março, de forma drástica as tarifas de importação para automóveis e diversos outros bens de consumo duráveis. Em seguida, adotaria quotas de importação para automóveis, entre outras medidas.

Ainda no mês de março, o Banco Central promoveria uma mididesvalorização do câmbio. Realizada de forma confusa e em momento de grande incerteza sobre o quadro internacional, tal iniciativa acabaria deflagrando um ataque especulativo contra o real. Em conseqüência, acentuou-se a perda de reservas e o Banco Central foi levado a promover alta dramática das taxas de juro em reais e a formalizar compromisso com um regime de bandas cambiais por prazo indeterminado.

Passou-se assim de um regime de banda informal, na faixa de 83 a 86 centavos de real por dólar, que vinha vigorando desde outubro de 1994, para uma banda explícita, com um piso de 88 e um teto de 93 centavos por dólar. A nova banda passou a ser protegida por taxas de juro extraordinariamente elevadas e pela disposição do governo de ampliar a oferta de títulos públicos indexados à taxa cambial. Essas mudanças na política comercial e cambial não eram, contudo, suficientes para reverter o quadro de desequilíbrio do balanço de pagamentos em conta corrente. As medidas de contenção à importação afetavam apenas uma parte da pauta e não resultaram em aumento expressivo da tarifa média (47). De qualquer forma, o raio de manobra do governo nessa área estava limitado pelo desaparelhamento dos órgãos encarregados de executar a política de comércio exterior e pelos compromissos assumidos com o Mercosul e a Organização Mundial de Comércio. Protestos de parceiros comerciais, notadamente da Argentina, logo levariam o governo brasileiro a recuar de algumas medidas de restrição à importação.

No campo da política cambial também não houve resultado expressivo do 
ponto de vista do ajuste da conta corrente. Tendo sido seguida da formalização de um banda estreita, a desvalorização nominal de março de 1995 não teve efeito duradouro sobre a posição da taxa de câmbio em termos reais, calculada com base em índices de preços ao consumidor. Como se vê na tabela 11 , a taxa bilateral com o dólar, deflacionada por índices de preços ao consumidor, retornou à posição de fevereiro em questão de apenas quatro meses. A partir daí, mantevese bastante estável, com leve tendência declinante.

Considerando-se uma cesta de taxas de câmbio, calculada pela Confederação Nacional da Indústria - CNI com base nas moedas dos dez principais parceiros comerciais do Brasil, a posição do real também não se modificou de modo duradouro (48). De acordo com a cesta de moedas utilizada pela CEPAL, o índice da taxa de câmbio efetiva da moeda brasileira situava-se, em 1995, nada menos que $55 \%$ abaixo do nível observado em 1987, acumulando uma valorização que mesmo o México e a Argentina não chegaram a registrar em momento algum nos últimos anos (tabela 8 ).

Nessas circunstâncias, a redução do desequilíbrio externo em conta corrente teria que depender fundamentalmente de uma drástica redução da demanda interna. No curto prazo, a forma mais fácil de diminuir a demanda era o controle do crédito interno. A política fiscal, que nunca tinha sido um dos pontos fortes do Plano Real, dificilmente poderia ser acionada com a rapidez requerida.

O que se fez, de março de 1995 em diante, foi fixar as taxas de juro básicas em nível dramaticamente mais alto e implementar um arsenal de restrições ao crédito em reais, em especial forte ampliação dos depósitos compulsórios sobre os depósitos à vista e a prazo e até mesmo a criação de um compulsório sobre os empréstimos bancários.

As taxas de juro internas subiram para níveis extraordinariamente elevados, mesmo para padrões brasileiros. Em maio, por exemplo, um levantamento das taxas de curto prazo em 38 países, amostra que inclui todas as principais economias desenvolvidas, a maioria das principais economias em desenvolvimento, além de alguns países do leste europeu, mostrava que as de taxas de juro praticadas no Brasil eram de longe as mais altas em termos reais (tabelas 14, 15 e 16).

Em termos nominais, só a Rússia e a Turquia registravam, naquele momento, taxas mais elevadas do que as do Brasil (tabela 16). Considerando as taxas de inflação, medidas pela evolução recente de índices de preços ao consumidor, nenhum país praticava taxas de juro sequer próximas aos $35 \%$ a.a. observados no Brasil. Naquele momento, a taxa real brasileira correspondia a nada menos que 15 vezes a média das taxas reais de juro nos sete principais países desenvolvidos (tabelas 14 e 16). Com juros reais de $22 \%$ a.a., a Argentina era o único outro país a apresentar taxa real superior a $20 \%$ a.a.

Note-se que esses dados referem-se, no caso do Brasil, ao overnight efetivo, lastreado em títulos públicos. Naturalmente, as taxas cobradas nos emprésti- 
mos do sistema bancário eram ainda mais elevadas. Em maio, as taxas de juro para capital de giro alcançaram nada menos que $8,8 \%$ ao mês, ou $176,4 \%$ ao ano. Deflacionado pela variação do INPC, o custo do capital de giro chegou a $115,4 \%$ a.a. Quando se considera o comportamento dos preços industriais no atacado, deflator mais relevante do ponto de vista da indústria, o custo real do crédito foi de $139,2 \%$ a.a. em maio. Para pessoas físicas, o custo do crédito atingiu 236,5\% a.a. em termos nominais e $162,2 \%$ a.a. em termos reais naquele mês (tabela 17).

A partir de meados de 1995, as taxas de juro começaram a cair em termos nominais e reais. Não obstante, um ano depois o custo do crédito em reais continuava excepcionalmente elevado: 64,8\% a.a. em termos reais para capital de giro, quando se considera o IPA-PI como deflator (tabela 17).

A alta dos juros e o arrocho sobre o crédito interno tinham, evidentemente, dupla função. A primeira era melhorar a conta de capitais do balanço de pagamentos, fortemente atingida pela crise mexicana. Com a elevação dos juros e a redução do crédito interno, o Banco Central procurava estancar a saída de capitais, atrair capitais estrangeiros de curto prazo e induzir as empresas brasileiras a tomar crédito externo e a trazer recursos próprios do exterior.

A segunda função era deprimir a demanda interna e o nível de atividade da economia, com o que se pretendia conter as importações, forçar as empresas a ampliar as exportações e favorecer a continuação da tendência de queda da taxa de inflação. A reversão da atividade econômica acabaria acontecendo de forma abrupta, a partir do segundo trimestre de 1995. Considerada a série do PIB trimestral com ajuste sazonal, a queda foi de $3,7 \%$ no segundo e de $1 \%$ no terceiro trimestres, com relação ao trimestre imediatamente anterior. Anualizada, a taxa de contração do PIB foi de $9,1 \%$ nesses dois trimestres, o que fez o nível de atividade retornar a patamar apenas $5 \%$ superior ao registrado imediatamente antes da reforma monetária. A recessão foi mais pronunciada no setor industrial, cuja produção acumulou queda anualizada de 19,1\% nesses dois trimestres (49).

Apesar da estabilização do câmbio real em nível deprimido e do caráter limitado das medidas de controle das importações, a política recessiva adotada a partir de março de 1995 foi suficiente para produzir efeitos significativos sobre o balanço de pagamentos. A balança comercial começou a reagir a partir de julho, movimento que pode ter sido apressado pela utilização de estoques de bens importados no início do ano, em antecipação às medidas de restrição das importações. No segundo semestre, o saldo comercial voltou a ser moderadamente positivo, alcançando US\$ 1,1 bilhão. O déficit em conta corrente caiu para US\$ 5,9 bilhões, cerca de metade do observado na primeira metade de 1995 (tabela 13).

A melhora da conta de capitais ocorreu de forma muito mais intensa em função das taxas de juro extravagantes praticadas no Brasil e da escassez de crédito interno. A partir de julho de 1995 a entrada líquida de capitais passou a superar o déficit em conta corrente e as reservas do Banco Central voltaram a aumen- 
tar. O superávit na conta de capitais alcançou nada menos que US\$ 23,4 bilhões no segundo semestre de 1995 (tabela 13).

Contrariando as expectativas formadas sob o impacto da crise do México, já em agosto as reservas no conceito de caixa ultrapassavam em mais de US\$ 6 bilhões o nível registrado em fins de novembro de 1994, imediatamente antes do colapso do peso mexicano (tabela 3 ). Ao mesmo tempo, a taxa de inflação diminuiu de modo apreciável no segundo semestre. Medida pelo IPC da Fipe, por exemplo, as taxas mensais médias caíram de 2,4\% no segundo trimestre de 1995 para $2 \%$ no terceiro e $1,3 \%$ no quarto $(50)$.

\section{EUA, México e Argentina}

A rápida reversão das contas externas brasileiras deve ser atribuída não só às medidas tomadas pelo governo brasileiro, mas também à sensível melhora no contexto financeiro externo a partir de abril/maio de 1995.

O governo norte-americano, com a ajuda do Fundo Monetário Internacional, veio em socorro do México (e dos investidores norte-americanos naquele país), anunciando uma operação de salvamento sem precedentes em termos do volume dos recursos envolvidos - mais de US\$ 50 bilhões - e da rapidez com que foram mobilizados, restabelecendo certa estabilidade nos mercados financeiros internacionais a partir de abril (51). Também para a Argentina organizou-se um pacote financeiro, de US\$ 4,7 bilhões, envolvendo recursos do FMI, Banco Mundial e BID (52). Além disso, a partir do segundo trimestre de 1995, revertendo movimento iniciado em fevereiro do ano anterior, as taxas de juro em dólares começaram a cair gradualmente no mercado internacional, reduzindo a pressão sobre "mercados emergentes" vulneráveis como México, Argentina e o próprio Brasil (53).

O mais importante, do ponto de vista norte-americano, foi a megaintervenção do governo Clinton ter conseguido evitar que o governo mexicano suspendesse o pagamento das suas obrigações externas, fato que teria certamente agravado de modo dramático a crise financeira internacional. Ao contrário do que ocorrera em 1982, quando a intervenção do governo norteamericano e das entidades multilaterais de crédito fora posterior à decretação de moratória pelo México, desta vez o governo dos EUA atuou de forma preventiva e conseguiu, por pouco, evitar que os mexicanos entrassem em default. Além disso, os EUA aproveitaram-se das dificuldades mexicanas para ampliar o seu controle e sua influência ao sul do Rio Grande, tendo inclusive obtido as receitas mexicanas de petróleo em garantia dos empréstimos bilaterais concedidos (54).

Naturalmente, as operações de socorro financeiro não eximiram o México e a Argentina de doloroso processo de ajuste já no primeiro semestre de 1995. No caso mexicano, a megadesvalorização cambial e a forte recessão conduziram a virtual equilíbrio no balanço de pagamentos em conta corrente em 1995 (tabela 2), mas à custa de forte aumento do desemprego, queda dos salários reais, 
aceleração significativa da inflação e graves dificuldades no sistema bancário. Em 1995, a taxa de inflação aumentou para mais de 50\% (55), pior resultado registrado desde 1987. A queda do PIB real foi de $6,8 \%$, superando em intensidade a recessão provocada pela crise da dívida externa no início dos anos 80 (56).

$\mathrm{Na}$ Argentina, o governo conseguiu preservar a paridade cambial e a lei de conversibilidade, obteve também melhora expressiva da posição externa em conta corrente (tabela 2), mas enfrentou recessão, elevação dramática das taxas de desemprego, além de grave crise bancária. A inflação continuou em declínio, mas a taxa de desemprego subiu para quase $20 \%$ e o PIB registrou queda de $4,4 \%$ em 1995 (57).

A deterioração só não foi maior porque, graças ao Mercosul e ao Plano Real, a Argentina pôde expandir fortemente as suas exportações para o Brasil em 1994-95, apesar da camisa-de-força imposta à política cambial argentina e da forte valorização do peso com relação ao dólar.

A valorização cambial produzida pelo Plano Real permitiu ao governo argentino obter parte da desvalorização de que necessitava, sem violar a lei de conversibilidade. Como a taxa de inflação argentina não tem sido muito diferente da dos EUA, a valorização do real com relação ao peso argentino foi da ordem de 30\% desde julho de 1994, semelhante à valorização do real com relação ao dólar. Admitindo-se que a ponderação do real na cesta de moedas relevante para o peso argentino seja de 20 a $25 \%$, a valorização do real correspondeu a mididesvalorização da ordem de 7\% do peso argentino nesse período.

Além disso, as exportações argentinas foram ajudadas pela forte expansão da demanda agregada no Brasil até março de 1995 e pelas condições privilegiadas de acesso ao mercado brasileiro propiciadas pelo Mercosul.

Ainda que tenha sido bastante elevado o custo do ajustamento para países como México e Argentina, o fato é que a instabilidade internacional diminuiu mais rapidamente do que muitos se arriscavam a prever sob o impacto da turbulência financeira do primeiro trimestre. Menos de um semestre após o início da crise, países como o Brasil, a Argentina e o próprio México começaram a voltar ao mercado internacional de capitais.

Em junho de 1995, o Banco Central brasileiro pôde anunciar, sem transtornos, um pequeno aumento e ampliação da banda cambial, que passou para a faixa de 91 a 99 centavos de real por dólar. Ao mesmo tempo, iniciou um movimento de diminuição gradual das taxas básicas de juro. Em janeiro de 1996, a banda cambial foi novamente alterada para 97 a 106 centavos de real por dólar, mais uma vez sem causar intranqüilidade nos mercados financeiros.

\section{Conseqüências internas do ajuste externo}

Embora não tenham alcançado a dimensão observada na Argentina e no México, os problemas internos provocados pelas políticas de ajuste e financia- 
mento dos desequilíbrios externos engendrados pelo Plano Real foram graves e se fizeram sentir quase imediatamente. Os acontecimentos seguiram um padrão familiar, recorrente em economias nas quais se procura sustentar um regime de ancoragem cambial com recurso a taxas de juro elevadas e restrições ao crédito doméstico.

Nessas situações, como observou Max Corden, até que a credibilidade da âncora cambial seja restaurada o governo tem que dispor de condições políticas para impor um período de taxas de juro extremamente elevadas: "In principle there is always some monetary policy - some very high domestic interest rate that can maintain a fixed exchange rate to which the country's monetary authorities have comitted themselves. (...) These high interest rates may need to be sustained for a long time, until the determination of the authorities to support the exchange rate becomes evident and the credibility of the existing exchange rate thus becomes established. There must be no doubt about the fundamentals, including the political commitment to the required tight monetary policy" (Corden, 1994:294).

Naturalmente, o problema está no preço que a economia doméstica paga durante a fase de juros altos: “(...) a very high interest rate sustained for any significant length of time will conflict with domestic objectives, having adverse effects on banks, on private borrowers, and on aggregate demand. It will also increase fiscal deficits owing to the higher cost of refinancing debt" (Corden, 1994:294).

Todos esses fenômenos manifestaram-se com grande intensidade a partir de meados de 1995. Empresas e consumidores que haviam aumentado rapidamente o seu endividamento, desde julho de 1994, tiveram a sua capacidade de pagamento duramente atingida por uma conjuntura marcada por queda das vendas domésticas, alta das despesas financeiras e desemprego, especialmente no setor industrial.

Nesse contexto, boa parte das empresas brasileiras passou a se ressentir de forma mais aguda da combinação de sobrevalorização cambial com abertura às importações, combinação essa que, apesar das dificuldades de balanço de pagamentos, ficara quase intacta.

O resultado foi uma onda de inadimplência que terminou por provocar forte abalo no sistema bancário. Desde julho de 1994, os bancos comerciais brasileiros haviam procurado se adaptar à queda dos ganhos associados à inflação com o aumento das tarifas bancárias e, especialmente, com a rápida expansão das operações de crédito. Assim, as restrições impostas ao crédito bancário e o aumento da inadimplência provocaram forte deterioração da qualidade dos ativos bancários (58).

No segundo semestre de 1995 o Banco Central foi obrigado a intervir em dois dos maiores bancos comerciais privados do país, o Econômico e o Nacional. Com isso, ficou claro que as dificuldades do sistema bancário brasileiro não esta- 
vam, ao contrário do que muitos pensavam, confinadas aos bancos públicos e aos de menor porte. À medida que se espalhou a desconfiança, outros bancos passaram a enfrentar dificuldades de liquidez, obrigando o governo a atuar intensamente no socorro às instituições financeiras mais vulneráveis.

Naturalmente, o setor público também pagou preço elevado pela correção do desequilíbrio das contas externas. A recessão afetou adversamente as receitas tributárias e elevou os saques do FGTS e despesas com o seguro-desemprego. A política de juros altos ampliou substancialmente o custo das dívidas de curto prazo do Tesouro, do Banco Central, dos estados e dos municípios. As dificuldades de refinanciamento das dívidas mobiliárias estaduais e municipais acabaram levando a que o Banco Central absorvesse grande parte desses papéis, substituindo-os por títulos federais. Durante todo o ano de 1995, mais de 75\% dos títulos estaduais e municipais em circulação ficaram em custódia no Banco Central (59).

A partir de julho de 1995, a esterilização do impacto monetário das operações cambiais contribuiu para a rápida expansão da dívida mobiliária federal fora da carteira do Banco Central. De junho de 1995 a junho de 1996 o estoque de títulos federais, de emissão do Tesouro e do Banco Central, aumentou $122 \%$, passando de R $\$ 69,5$ bilhões para R $\$ 154,3$ bilhões. Em função da remonetização provocada pela queda da inflação, a razão dívida mobiliária federal/PIB caíra de $12,9 \%$ em junho de 1994 para $11,5 \%$ em dezembro de 1994 e se estabilizara em torno desse nível no primeiro semestre de 1995. Com a retomada dos superávits na conta de capital do balanço de pagamentos a partir de julho, a dívida em títulos voltou a crescer como proporção do PIB, chegando a 16,2\% em dezembro de 1995 e a $21,7 \%$ em junho de 1996 (60). A expansão da dívida pública, a partir de julho de 1995, refletiu também a assistência financeira aos bancos, realizada no âmbito do Programa de Estímulo à Reestruturação e ao Fortalecimento do Sistema Financeiro Nacional - PROER e por meio de outros mecanismos (61).

Em conseqüência desses e outros fatores, os resultados consolidados do setor público acusaram forte deterioração ao longo de 1995. O superávit primário do setor público (incluindo governo federal, Banco Central, governos estaduais e municipais e empresas estatais federais, estaduais e municipais) diminuiu de 5,16\% do PIB em 1994 para 0,37\% do PIB em 1995 (62). Nesse período, a carga de juros reais sobre as dívidas internas e externas aumentou de $3,82 \%$ do PIB para $5,36 \%$. Assim, o resultado operacional do setor público passou de um superávit de 1,34\% do PIB em 1994 para um déficit de 4,99\% em 1995 (tabela 18), um aumento do déficit equivalente a nada menos que $6,3 \%$ do PIB em apenas um ano!

No primeiro semestre de 1996, a situação fiscal continuou problemática, a despeito da queda das taxas de juro incidentes sobre a dívida pública, do congelamento dos salários do funcionalismo federal e de reajustes inferiores à inflação para o salário mínimo e os benefícios previdenciários (63). Relativamente ao primeiro semestre de 1995, o déficit aumentou de forma significativa nos conceitos nominal, operacional e primário (tabela 18). 
Déficit público dessa ordem de magnitude é perigosamente alto para um país que acaba de emergir de grave crise inflacionária e onde o setor público ainda não pode contar com acesso expressivo a financiamento de longo prazo. Nessas condições, um déficit fiscal acaba sendo coberto essencialmente com acumulação de passivos de curto prazo.

No que diz respeito aos resultados fiscais, o desempenho do Plano Real parece estar sendo inferior ao dos programas de estabilização mexicano e argentino. No período 1991-94, por exemplo, México e Argentina registraram em suas contas públicas, respectivamente, superávit médio de 1,3\% do PIB e déficit médio de $0,5 \%$ do PIB (64).

Sustentado em grande medida pela combinação de juros altos e câmbio sobrevalorizado, o Plano Real vai se tornando potencialmente mais vulnerável a ataques especulativos. Pelo menos é o que sugere a evolução da liquidez doméstica em comparação com a das reservas. Como se sabe, uma das maneiras de se tentar avaliar a sustentabilidade, no médio prazo, de um programa ancorado no câmbio é examinar o grau de cobertura proporcionado pelas reservas internacionais ao estoque de liquidez doméstica, definido para incluir não apenas a base monetária convencional, mas também outros passivos de curto prazo do Tesouro e do Banco Central.

Em junho de 1994, logo antes da criação do real, as reservas do Banco Central, no conceito de caixa, correspondiam a $57,4 \%$ da base monetária ampliada, definida pelo Banco Central como a soma da base monetária restrita com depósitos compulsórios em espécie e títulos federais. Um ano depois, a relação entre as reservas e a base ampliada caiu para 35,2\%. Em junho de 1996, essa relação alcançou apenas $37,4 \%$, a despeito do crescimento extraordinariamente rápido das reservas desde julho de 1995 (tabela 19). A dívida mobiliária federal, com vencimentos concentrados no curto prazo (65), correspondia a $153,7 \%$ das reservas internacionais em junho de 1994. Dois anos depois, essa relação aumentou para $262 \%$ (tabela 19 ).

Os resultados fiscais aparecem agora mais claramente como ameaça à consolidação do programa de estabilização, tanto mais que com o passar do tempo, e a despeito da redução gradual das taxas de juro e de uma certa flexibilização das restrições ao crédito, multiplicam-se as demandas de alívio tributário e socorro financeiro da parte de setores com poder de pressão e duramente atingidos pela política macroeconômica do governo federal, como a agricultura, estados e municípios, sistema bancário, entre outros.

Na medida em que o governo federal é levado a ceder a essas pressões, reforça-se a percepção de que a base fiscal do programa de estabilização está sofrendo erosão significativa. Nessas circunstâncias, a lenta tramitação no Congresso e as resistências políticas a projetos considerados fundamentais, como a privatização de empresas estatais, as reformas tributária, previdenciária e administrativa, alimentam dúvidas quanto à consistência e sustentabilidade da política econômica do governo. O período de transição no qual o Plano Real ficaria 
temporariamente sustentado pelas políticas de juro e de câmbio vai sendo prorrogado indefinidamente.

Paradoxalmente, os mecanismos transitórios, cuja função original era dar tempo até que se superassem os problemas financeiros do setor público, vêm contribuindo para agravá-los e para retardar a consolidação do programa de estabilização.

\section{A eternização do temporário}

O Plano Real completou dois anos com inflação decrescente, mas sem ter superado as suas principais vulnerabilidades e inconsistências. Grande parte do setor produtivo continua sofrendo as conseqüências dolorosas da combinação de juros altos e câmbio sobrevalorizado. Contudo, as autoridades governamentais repetem insistentemente que a política econômica, especialmente no que se refere a câmbio e juros, continuará na sua trajetória recente.

De certo ponto de vista, esse conservadorismo pode parecer justificado. Afinal, com a atual política econômica, o governo conseguiu reequilibrar o balanço de pagamentos e até mesmo sobrefinanciar o déficit em conta corrente, voltando a acumular reservas a partir de julho de 1995. E mais: manteve as taxas de inflação em queda, preservando o seu trunfo político fundamental.

No que diz respeito à redução da inflação, o programa de estabilização em curso é o mais bem-sucedido dos últimos 30 anos no Brasil. Os seus resultados também se comparam de modo bastante favorável com os de programas de combate à inflação realizados em outros países. Nos primeiros dois anos do Plano Real, as taxas de inflação foram mais baixas do que, por exemplo, no caso do programa de estabilização mexicano (66), que até a crise de dezembro de 1994 era apontado urbi et orbi como referência exemplar para o resto da América Latina. E foram apenas um pouco mais altas do que as registradas pela Argentina nos dois primeiros anos do também celebrado Plano Cavallo (67).

Seguindo o exemplo de outros governos latino-americanos, o governo Fernando Henrique Cardoso explicitou de modo inequívoco a sua ordem de prioridades no campo econômico: combate à inflação acima de tudo e ainda que à custa de juros elevados, câmbio sobrevalorizado, recessão ou crescimento medíocre e desemprego crescente.

Não há, a rigor, nada de surpreendente nisso. A lição óbvia da experiência econômica e política da América Latina nos anos 80 e 90 - vide Argentina, Bolívia, Peru e o próprio Brasil - é a imensa popularidade dos programas de estabilização em sociedades traumatizadas pela hiperinflação ou por longos períodos de inflação alta. Nessas condições, as expectativas e exigências do eleitorado, particularmente da população de baixa renda, parecem ser bastante modestas e os governos que conseguiram se apoderar da bandeira do combate à inflação têm alcançado grandes dividendos políticos, mesmo quando são significativos os cus- 
tos sociais das políticas antiinflacionárias. Só mais recentemente, depois do colapso do programa econômico do México em fins de 1994 e de um período prolongado de desemprego extremamente elevado na Argentina em 1995-96, é que o trunfo político-eleitoral representado pelo sucesso no combate à inflação começou a dar sinais de esgotamento.

O governo brasileiro, até pela forma como se elegeu, não poderia deixar de pautar a sua estratégia de política econômica pela preocupação com o combate à inflação. Não tendo sido ainda capaz de encontrar uma base de apoio alternativa para a estabilização, prefere continuar agarrado à âncora cambial, sustentada por juros altos e pela esperança de que não voltem a ocorrer turbulências financeiras internacionais. É de se esperar, portanto, que persista o quadro de sobrevalorização cambial e que a redução das taxas de juro, iniciada no segundo semestre de 1995, continue ocorrendo de forma gradual, até o limite definido pelas condições do setor externo da economia e pela oferta de liquidez internacional.

O que era para ser temporário, vai se incorporando permanentemente à paisagem. Enquanto há financiamento externo em quantidade apreciável ou enquanto a sociedade tolera as agruras da recessão e do desemprego, a tendência é postergar qualquer ajuste mais fundamental.

A possibilidade de romper os impasses do Plano Real depende, em grande medida, da consolidação das finanças públicas. Um progresso perceptível em termos de ajustamento fiscal, combinado com pragmatismo e flexibilidade na condução das políticas monetária e cambial, abriria caminho para livrar a economia da destrutiva combinação de juros altos e câmbio supervalorizado. Se realizada de forma cuidadosa e no momento apropriado, uma correção cambial contribuiria inclusive para criar um contexto macroeconômico propício ao ajustamento das contas públicas, ao permitir que a economia operasse com taxas de juro menores e nível de atividade mais alto (68).

A demora em enfrentar os problemas pendentes pode causar grandes transtornos. Um período prolongado de câmbio relativamente estável, combinado com juros internos elevados e crédito escasso em moeda doméstica, induz à dolarização dos passivos das empresas e até mesmo das famílias, sobretudo se houver remoção de restrições à contratação de créditos em moeda estrangeira. À medida que passa o tempo, aumenta o número de agentes endividados em moeda estrangeira que não dispõem de acesso a mecanismos de hedge ou que não têm receitas em moeda estrangeira. Com isso, cresce a resistência ao ajustamento cambial. O temor de gerar turbulência financeira doméstica pode levar à imobilização progressiva da política cambial. No limite, o Brasil terminaria numa situação próxima à da Argentina, a despeito da maior flexibilidade institucional do seu regime monetário e cambial.

Seria fundamental, portanto, criar desde logo condições para uma correção da taxa cambial. Contudo, como foi indicado, isso depende em parte do fortalecimento das bases fiscais do programa de estabilização. Vimos que o ajus- 
tamento das contas públicas vem sendo prometido e anunciado desde os tempos em que o atual presidente da República era ministro da Fazenda. Em 1993-94, o ajuste fiscal - denominado pomposamente de mudança do regime fiscal - era anunciado como precondição da reforma monetária. Depois, passou à condição de fator indispensável à consolidação do programa de estabilização em 1995. Agora, foi transferido para 1996 ou 1997.

Em 1995, ao invés de avançar na consolidação fiscal do programa, o governo permitiu forte deterioração dos resultados fiscais, provocada em parte por recessão e juros altos e por pressões quase-fiscais, como o custo de carregamento das reservas internacionais e as operações de socorro a bancos públicos e privados. A política fiscal continuou dependendo da prorrogação ou reintrodução de mecanismos originalmente anunciados como provisórios, a exemplo do chamado Fundo Social de Emergência - FSE (agora redenominado Fundo de Estabilização Fiscal - FEF) e o Imposto Provisório sobre Movimentação Financeira $\operatorname{IPMF} \bullet($ agora Contribuição Provisória sobre Movimentação Financeira - CPMF), e de providências ad hoc, como contenção dos reajustes do funcionalismo, redução real do salário mínimo e outras medidas de repressão de despesas.

O governo reconhece, pelo menos retoricamente, a fragilidade fiscal do programa de estabilização e os efeitos perversos de um período de juros altos. Mas a coalizão política que o sustenta, integrada pelos setores que sempre conviveram sem problemas com, ou até se beneficiaram do regime inflacionário e da indisciplina fiscal e financeira, freqüentemente nega o apoio a mudanças de fundo no campo da organização, controle e financiamento do Estado brasileiro.

Não se pode, portanto, dizer que o quadro seja dos mais animadores. Se a economia se reativar de forma significativa, o desequilíbrio externo voltará a aumentar, agravando a vulnerabilidade financeira do país. Por outro lado, se a economia continuar em recessão ou crescer pouco, ficará mais difícil resolver os problemas que dominaram a agenda econômica desde o segundo semestre de 1995: desemprego, fragilidade do sistema financeiro e déficit público.

\section{Crescimento econômico e desequilíbrio externo}

A recuperação das contas externas e a melhora do contexto financeiro internacional permitiram que o Banco Central promovesse afrouxamento das restrições ao crédito interno e redução gradativa das taxas básicas de juro a partir de meados de 1995. Essa ampliação do crédito produziu efeitos positivos sobre a demanda interna e o nível de atividade.

Entretanto, a reativação em curso, embora significativa (69), não vem sendo suficiente para reduzir o desemprego de forma apreciável. Em meados de 1996, as taxas de desemprego eram mais altas do que em igual período de 1994 e 1995, e iguais ou superiores às registradas durante a recessão do início dos anos 90 (70). O quadro é particularmente grave na indústria, setor que oferece, em geral, empregos mais bem remunerados e de melhor qualidade (71). 
A economia poderia crescer mais sem provocar reversão da tendência de queda da inflação? Há razões para acreditar que sim. Existe capacidade produtiva ociosa, acumulada desde os anos 80, durante o longo período de recessão ou crescimento medíocre. No passado recente houve vários casos de países que conseguiram sucesso no combate à inflação, crescendo a taxas bem mais elevadas do que os $3 \%$ ou $4 \%$ ao ano que o Brasil vem registrando em 1995-96. Foi o que aconteceu no Chile de 1990 a 1995, período em que a inflação ao consumidor caiu de $27 \%$ para $8 \%$ ao ano e o PIB real cresceu à taxa de $7 \%$ ao ano em média. Também foi o caso da Argentina, entre 1991 e 1994, quando se conseguiu trazer a taxa de inflação para níveis internacionais, com a economia crescendo quase $8 \%$ ao ano em média (72).

A principal restrição ao crescimento brasileiro é de outra natureza. Como já foi indicado, o problema central é o efeito do crescimento da demanda e da produção sobre a balança comercial e a conta corrente do balanço de pagamentos, no quadro de uma economia mais aberta às importações e submetida a uma valorização significativa e persistente da taxa cambial. Infelizmente, o Brasil aproxima-se, nesse particular, mais da Argentina do que do Chile. Recorde-se que uma das razões pelas quais o Chile tem posição mais sólida reside justamente no fato de ter adotado, em todo o período recente, políticas cambiais prudentes, o que permitiu que a economia crescesse sem gerar desequilíbrios externos perigosos (tabelas 2 e 8 ).

No caso do Brasil, a taxa mínima de crescimento do PIB que seria adequada do ponto de vista da geração de empregos, algo como 6\% ao ano, tende a se revelar excessiva do ponto de vista da balança comercial e do balanço de pagamentos em conta corrente. Por outro lado, uma taxa de crescimento compatível com segurança nas contas externas, mostra-se insuficiente do ponto de vista da geração de empregos.

Em determinadas circunstâncias, pode aparecer discrepância entre a taxa interna de juro compatível com um crescimento adequado da demanda interna e aquela que se faz necessária para gerar um superávit suficiente na conta de capitais do balanço de pagamentos. É o que acontecerá se houver, por exemplo, nova rodada de aumentos nas taxas de juro nos mercados financeiros internacionais. Nessa hipótese, a política de juros adequada para estimular o ingresso do capital requerido para cobrir o déficit em conta corrente e refinanciar os vencimentos de curto prazo pode se revelar, outra vez, incompatível com as prioridades internas de crescimento, geração de empregos, ajuste fiscal e estabilidade do sistema financeiro.

Ressalte-se que esses dilemas não são fruto de alguma fatalidade macroeconômica. Trata-se fundamentalmente do resultado de opções ou omissões da política econômica brasileira. Não se poderia esperar outro resultado de uma estratégia macroeconômica que vem penalizando a produção nacional e que, de modo geral, não assegura às empresas brasileiras condições eqüitativas na com- 
petição com os seus concorrentes internacionais, seja nos mercados externos, seja na competição com importações nos mercados domésticos.

Apesar de algumas medidas setoriais de proteção ou estímulo adotadas depois da crise mexicana, a orientação geral da política econômica brasileira ainda carrega um viés que tende a diminuir a competitividade internacional da economia.

As razões deste viés são conhecidas. Uma delas é a estrutura tributária brasileira, que ainda não foi inteiramente adaptada ao processo de abertura da economia. O problema não está apenas na incidência de impostos sobre exportações, como era o caso do Imposto sobre Circulação de Mercadorias e Serviços ICMS sobre produtos primários e semi-elaborados até setembro de 1996, mas também na presença de importantes tributos em cascata, como a Contribuição para o Financiamento da Seguridade Social - COFINS e o Programa de Integração Social - PIS, que representam pesada carga sobre o faturamento das empresas. A aprovação da Contribuição Provisória sobre Movimentação Financeira - CPMF, que entrará em vigor no início de 1997, contribui para agravar o problema, na medida em que representa a introdução de mais um tributo cumulativo, que onera o custo Brasil, na contramão da suposta preocupação do governo com o tema.

Outra razão da perda de competitividade internacional é o elevado componente financeiro do custo local de produção, que prejudica sobretudo as pequenas e médias empresas, as que têm menos acesso a crédito em moeda estrangeira. No segundo trimestre de 1996, as taxas de juro para financiamento de capital de giro ainda eram da ordem de $65 \%$ a $70 \%$ em termos reais, quando se utiliza o índice de preços industriais no atacado como deflator (tabela 17).

A isso acrescentou-se uma abertura comercial mal-preparada, que reduziu substancialmente as barreiras tarifárias e não-tarifárias à importação desde 1990 . Não houve modernização da política comercial e a abertura acabou sendo feita sem que fossem adotadas cautelas mínimas em termos de salvaguardas e ordenamento do comércio exterior.

Mas o ponto nevrálgico é a taxa de câmbio. O Plano Real provocou, como vimos, modificação drástica do valor externo da moeda brasileira. Vimos também que a valorização produzida pelo Plano Real se sobrepôs à significativa valorização ocorrida em anos anteriores.

Desde junho de 1994, mês imediatamente anterior à reforma monetária, até junho de 1996, a taxa de câmbio com o dólar, ajustado por índices de preços ao consumidor, acusou valorização extraordinária, de nada menos que $33 \%$, acumulada basicamente no segundo semestre de 1994, logo antes do colapso do México (tabela 11).

De 1995 em diante, a política cambial brasileira tornou-se mais prudente, e a taxa nominal voltou a ser desvalorizada. No entanto, essas desvalorizações nominais não reverteram o processo anterior de valorização real. $\mathrm{O}$ câmbio foi 
silenciosamente reindexado, mas não houve correção em termos reais. Ao contrário, a taxa de câmbio real continuou a sofrer gradual apreciação (tabela 11).

Em outras palavras: tornou-se mais caro produzir bens e serviços no país e as empresas brasileiras ficaram em desvantagem, seja nos mercados externos, seja na competição com produtores estrangeiros no mercado nacional. Entre junho de 1994 e junho de 1996 os preços ao consumidor no Brasil, medidos em dólares, aumentaram nada menos que $69 \%$, quando se considera o índice nacional de preços ao consumidor da Fundação Getúlio Vargas (73). No mesmo período, os preços ao consumidor nos EUA aumentaram apenas $6 \%$ (74).

Os salários, medidos em dólares, também cresceram de forma expressiva. Entre junho de 94 e junho de 96, os salários médios na indústria brasileira aumentaram $45 \%$ em dólares. A relação câmbio salário caiu 31\% nesse período (tabela 12).

O que ninguém até agora conseguiu explicar é como o Brasil vai conseguir operar a mágica de compensar essa imensa valorização cambial com ganhos de produtividade e redução do custo Brasil. Tanto mais que, como ficou evidente no caso da aprovação da CPMF, a política do governo nem sempre é consistente com esse objetivo.

O governo insiste, com certa razão, em destacar o nível de reservas internacionais como fator que proporciona segurança à economia. No primeiro semestre de 1996, as reservas continuaram crescendo, tendo alcançado US\$ 58,6 bilhões no final de junho (tabela 3 ). Ocorreu, além disso, alguma melhora na qualidade dos ingressos de capital. Os prazos médios dos empréstimos externos captados pelo Brasil têm aumentado. Aumentou também, e de forma significativa, o influxo de investimentos diretos estrangeiros (75). Espera-se que, em 1996, o ingresso líquido de investimentos diretos possa alcançar mais de US\$ 7 bilhões.

São fatos positivos, mas não podem ser considerados suficientes para tirar a economia da trajetória de risco em que foi colocada pela valorização cambial e pela abertura pouco criteriosa às importações.

Vale a pena registrar que em 1994 o México recebeu nada menos que US\$ 8 bilhões sob a forma de investimentos diretos estrangeiros, fato que não impediu a eclosão de uma grave crise cambial em dezembro daquele ano (76). A experiência do próprio México e de muitos outros países mostra, também, que um estoque de reservas elevado pode sofrer rápida erosão diante da volatilidade do capital financeiro, não só de estrangeiros, como de nacionais. Recorde-se que o banco central do México começou o ano fatídico de 1994 com reservas (exclusive ouro) consideradas confortáveis, de US\$ 25,1 bilhões (77).

Por outro lado, cabe notar que, em determinadas circunstâncias, reservas elevadas podem se converter em uma fonte de problemas. E não apenas porque o seu carregamento tem alto custo financeiro para o governo federal. 
O Banco Central alega que as reservas elevadas constituem uma apólice de seguro contra turbulências externas. Mas a lógica do argumento é duvidosa. Tendo sido constituídas em grande medida com capitais voláteis ou de curto prazo, as reservas diminuiriam com rapidez na hipótese de materialização dos riscos contra os quais elas constituem um suposto seguro. Queda abrupta das reservas, provocada por fuga de capitais especulativos, reforçaria a insegurança $\mathrm{e}$ poderia degenerar em pânico. A apólice de seguro acabaria se convertendo em uma apólice de risco.

Esse paradoxo foi apontado por Keynes, quando examinou os princípios de regulação das reservas dos banco centrais no Treatise on money. "Public opinion is always content with what it is used to", observou ele, "so that it is, indeed, a source of weakness to get the public into the habit of expecting the permanent and continuos maintenance of large free reserves (...)" (Keynes, 1930b:p.246).

O setor externo da economia brasileira não é tão vulnerável quanto era o mexicano em 1992-94. Mas um exame dos dados brasileiros continua revelando pontos frágeis. É sintomático que a recuperação do nível de atividade já tenha sido suficiente para produzir significativa deterioração da balança comercial no primeiro semestre de 1996 (tabela 13). A tendência ao desequilíbrio aparece mais claramente quando se considera a sazonalidade dos fluxos comerciais (78).

Vamos admitir, a título de ilustração do argumento, que a balança comercial apresente um déficit anual da ordem de US\$ 5 bilhões nos próximos anos. Como o desequilíbrio na conta corrente exclusive comércio deve ficar em torno de US\$ 15 bilhões, em função dos juros da dívida externa e de outras despesas, pode-se prever que o déficit total em conta corrente alcance cerca de US\$ 20 bilhões por ano.

Como se sabe, déficit em conta corrente gera aumento do passivo externo líquido do país, dado que o seu financiamento implica aumento da dívida externa (líquida de reservas internacionais do banco central e outros créditos do país contra o exterior) ou do estoque de investimentos estrangeiros (líquido de investimentos do país no exterior). Dadas as taxas médias de juros e de remessa de lucros e dividendos, esse aumento do passivo externo líquido provoca, por sua vez, aumento da renda líquida enviada ao exterior em períodos subseqüentes. Portanto, a menos que diminua o déficit comercial e com serviços não-fatores, ou que aumentem as remessas de emigrantes e outras transferências unilaterais, o déficit em conta corrente tenderia a aumentar nos próximos anos.

Além disso, há que se considerar a concentração de vencimentos da dívida externa em 1996 e, sobretudo, em 1997. De acordo com dados do Banco Central, as amortizações de médio e longo prazos serão da ordem de US\$ 13 bilhões em 1996. Em 1997, chegarão a cerca de US\$ 18 bilhões (79). A necessidade bruta de capital externo será, portanto, da ordem de US\$ 40 bilhões no próximo ano, sem contar o refinanciamento dos passivos externos de curto prazo. 
Enquanto a liquidez internacional for adequada e os mercados financeiros permanecerem abertos para o Brasil, não será impossível refinanciar os passivos de curto prazo, as amortizações de médio e longo prazos e obter recursos líquidos adicionais. Mas, depois da crise do México, seria temeridade não trabalhar com a hipótese de que voltem a ocorrer turbulências financeiras externas ou dificuldades de captação de recursos para países como o Brasil.

Não estando, por enquanto, ameaçado de colapso cambial ou de crise fiscal no curto prazo, o Brasil tem tempo e condições de acertar o passo e completar o processo de estabilização iniciado com sucesso em 1994.

Mas para que isso seja possível, é preciso ter percepção realista dos problemas pendentes, alguns dos quais resultaram da própria maneira como se processou a estabilização monetária nos últimos dois anos. E é preciso evitar que o sucesso incial em termos de redução da inflação tenha o efeito perverso de anestesiar o país, impedindo-o de reconhecer a natureza dos desafios que ainda tem pela frente para consolidar o processo de estabilização e abrir caminho para uma nova etapa de desenvolvimento sustentado.

\section{Notas}

1 Medida por um índice de preços ao consumidor, a inflação argentina em 12 meses ficou abaixo de 4\% a partir maio de 1994 (Comisión Económica para América Latina y el Caribe, 1995a, p. 22).

2 Idem, p. 60. Em 1994, a taxa de inflação nos EUA ficou em 2,7\% (Banco Central do Brasil, ago. 1995, p. 185). Os dados referem-se a variações de índices de preços ao consumidor.

3 Comisión Económica para América Latina y el Caribe, 1995b, p. 140, 270.

4 Banco Central do Brasil, ago. 1995, p. 184.

5 Sobre a experiência chilena ver, por exemplo, Ffrench-Davis, Agosin \& Uthoff, 1995. $\mathrm{Na}$ Colômbia, a redução de tarifas de importação foi antecedida de uma grande desvalorização da taxa de câmbio (Hommes, 1995, p. 50).

6 Para uma avaliação do acordo com os bancos comerciais, assinado em abril de 1994, ver Batista Jr. \& Rangel, 1994.

7 Banco Central do Brasil, ago. 1995, p. 132. Posteriormente, o Banco Central reviu a metodologia de estimação do PIB mensal. Pela nova metodologia, a razão dívida/PIB alcançava 12,9\% em junho de 1994 (Banco Central do Brasil, 23. nov. 1995, Quadros XIV e XV).

$8 \mathrm{O}$ governo chegou a condicionar a reforma monetária à revisão constitucional. $\mathrm{Na}$ exposição de motivos da medida provisória que criou a URV, datada de 27 de fevereiro de 1994, o governo deixava claro que o FSE deveria ser visto como mecanismo de transição: "Uma vez feitas as conversões contratuais [via URV] e definidas as novas 
regras monetárias, o país poderá ingressar na fase da moeda estável. Pois, nessa oportunidade, o equilíbrio orçamentário temporariamente garantido pelo Fundo Social de Emergência já deverá estar garantido de forma duradoura pela aprovação, no Congresso Revisor, das emendas constitucionais de reforma do Estado brasileiro e pela aceleração do processo de privatização" (Presidência da República, 1994a, p. 6).

9 O FSE foi aprovado por meio da Emenda Constitucional de Revisão $n^{\circ} 1$, de $1^{\circ}$ de março de 1994, tendo como fonte de receitas $20 \%$ do produto da arrecadação de todos os impostos e contribuições da União, mais a parcela da arrecadação resultante do aumento de alíquotas ou da alteração da base de cálculo de alguns tributos (Banco Central do Brasil, 1994, p. 63).

10 Ver, por exemplo, Ministério da Fazenda, 1993, p. 22 e Presidência da República, 1994b, seção 1, p. 9768.

11 Para uma crítica dessa alternativa e em especial da conveniência de aplicá-la ao Brasil, ver Batista Jr., 1993c.

12 Comisión Económica para América Latina y el Caribe, 1995b, p. 99.

13 Banco Central do Brasil, ago.1995, p. 54.

14 Em fins de fevereiro de 1986 e março de 1990, as reservas no conceito de caixa estavam, respectivamente, em US\$ 7,1 bilhões e US\$ 5,4 bilhões (Banco Central do Brasil, 1987$, p. 82,$85 ; 1992$, p. 95,97$)$.

15 International Monetary Fund, 1993, S388, S390, S603. O dado de reservas exclui as reservas de ouro; o de importação exclui as importações das empresas maquiladoras.

16 Batista Jr., 1993b, p. 11. O dado de reservas inclui as reservas de ouro.

17 Banco Central do Brasil, ago. 1995, p. 161.

18 Banco Central do Brasil, dez.1994, p. 134-5; out. 1995, p. 167. Ver, também, Faria, 1994, p. 13.

19 Os tesobonos são títulos do governo vinculados ao dólar. Cerca de $80 \%$ estavam em mãos de não-residentes (American Express Bank, 1995, p. 16).

$20 \mathrm{O}$ ministro da Fazenda, Pedro Malan, por exemplo, em entrevista à imprensa internacional, em Washington, afirmou que no momento da sua introdução, o real estava subvalorizado e não apreciado (O Estado de S.Paulo, 13 out. 1995, p. B 7).

21 International Monetary Fund, 1993, p. S90, S390, S603. Os dados de comércio exterior do México excluem as exportações e importações de empresas maquiladoras.

22 Idem, p. S90, S390.

23 Banco Central do Brasil, ago. 1995, p. 182.

24 Ver Ministério da Fazenda, 1993, p. 17-8; Presidência da República, 1994a, p. 2-3; e Presidência da República, 1994b, seção 1, p. 9767.

25 Presidência da República, 1994b, seção 1, p. 9761. 
26 A medida provisória autorizava o Conselho Monetário Nacional a alterar os tetos de emissão em até $20 \%$, "para atender situações extraordinárias" (Idem, ibidem).

27 Ver, por exemplo, Goodhart, 1995, p. 219-22. Em trabalho recente, Stanley Fischer observa que a instabilidade da demanda por moeda que se manifestou em muitos países nos anos 70 e 80 inviabilizou o recurso a regras monetárias simples: "There cannot be a case now for (...) putting in place any rule that prescribes by a fixed formula the growth rate of any monetary aggregate or the behaviour of interest rates. Rather, the monetary authorities need to be given flexibility to decide on day to day monetary policy" (Fischer, 1994, p. 289).

28 Tampouco parece plausível explicar a queda inicial da inflação nos programas de estabilização do México e da Argentina com base em análises inspiradas no paradigma Sargent-Lucas, no qual a estabilização monetária resultaria supostamente de uma abrupta reversão das expectativas ou de um choque de credibilidade decorrente de uma mudança do regime fiscal-monetário. Mesmo no caso argentino, em que uma interpretação desse tipo ainda poderia ser defensável, a precariedade da posição inicial das finanças públicas é um fato digno de nota (Batista Jr., 1993a, p.150).

29 Ver Popper (1959), especialmente p. 27-30, 34-42. Ver, também, Blaug, 1980, p.10-3, 17-20. Para Blaug, "the central weakness of modern economics is, indeed, the reluctance to produce the theories that yield unambiguosly refutable implications, followed by a general unwillingness to confront those implications with the facts" (Idem, p. 254).

30 Banco Central do Brasil, Relatório 1994 , p. 100.

31 Restrições mais significativas à entrada de capitais só viriam a ser introduzidos em outubro (Idem, p. 100-102).

32 Confederação Nacional da Indústria, 1995, p. 23.

33 Na já citada entrevista à imprensa internacional, o ministro da Fazenda, Pedro Malan, por exemplo, considerou "absolutamente erradas" as estimativas de que existiria "uma sobrevalorização de $20 \%, 30 \%$ ou $40 \%$ ". Malan não negou a existência de "uma pequena apreciação", mas declarou que as estimativas "da maioria dos analistas sérios, que acreditam que há uma sobrevalorização significativa da moeda, estão no nível de um dígito"( O Estado de S.Panlo, 13 out. 1995, p. B 7).

34 Documento divulgado pelo Ministério da Fazenda, em junho de 1995, estimava em apenas $14,5 \%$, em termos reais, a apreciação do real em relação ao dólar na comparação da posição de abril de 1995 com a de julho de 1994. A estimativa apresentada no documento oficial, de responsabilidade da Fundação Centro de Estudos do Comércio Exterior - FUNCEX, baseava-se no IPA-DI (índice de preços por atacado - disponibilidade interna) da FGV. Os principais trechos desse documento foram reproduzidos na Gazeta Mercantil, 3 jul. 1995, Relatório: Um Ano do Real, p. 6. A FUNCEX estima em 16\% a apreciação real acumulada, em relação ao dólar, de junho de 1994 até maio de 1996, tomando como deflatores índices de preços atacadistas nos EUA e no Brasil (IPA-DI). Fundação Centro de Estudos do Comércio Exterior, 1996, p. 2, 4, 9. Todos as estimativas agregadas de câmbio real apresentadas pela FUNCEX baseiam-se em índices de preços no atacado. 
$35 \mathrm{O}$ mesmo fenômeno ocorreu durante os programas de estabilização do México em 1988-91 e da Argentina em 1991-93 (Comisión Económica para América Latina y el Caribe, 1995b, p. 140, 270).

36 No Treatise on money, publicado cinco anos depois da restauração do padrão-ouro, Keynes escreveu: "I do not believe that Great Britain would have returned in 1925 to the gold standard at the pre-war parity if it had not been for the habit of regarding the wholesale standard as a satisfactory indicator of general purchasing power" (Keynes, 1930a, p. 79). Seguindo Marshall, Keynes considerava que o poder de compra geral da moeda deveria ser medido por índices de preços ao consumidor (Idem, p. 47-49).

37 At the time of Great Britain's return to the gold standard the Treasury and the Bank of England were led to the false conclusion that, because the wholesale index, which was almost the same thing as the British international index, was moving rapidly into adjustment - as an international index necessarily must - with the movement of the gold exchanges, therefore the same thing was true of 'prices generally" (Idem, p. 66). Keynes atribuía o "prestígio" da chamada teoria da paridade do poder de compra ao fato de que muitos dos principais índices de preços atacadistas eram compostos primordialmente dos preços de tradeables, então denominados unsheltered prices (Idem, p. 62, 65). Para ele, o próprio responsável pela elaboração dessa teoria, o economista sueco Gustav Cassel, tinha incorrido no erro de aplicar fora do seu campo apropriado conclusões válidas apenas para um tipo particular de índices de preços, os índices de preços internacionais (Idem, p. 66).

38 Observe-se, de passagem, que a rigidez do esquema monetário e cambial que vigora na Argentina desde 1991 é muito maior do que geralmente se imagina no Brasil. A lei monetária de abril de 1991 não apenas fixou um teto para a taxa de câmbio com o dólar, mas garantiu a conversibilidade da moeda e subordinou a emissão monetária às reservas. Além disso, criou-se um sistema bimonetário no país, na medida em que se concedeu pleno respaldo legal às operações realizadas em dólares. Como explicou o então ministro da Economia, Domingo Cavallo, em trabalho escrito em co-autoria com Guillermo Mondino e publicado pelo Banco Mundial, "the convertibility program (...) allowed for two (or more) currencies to compete against each other in the domestic market. When the program was introduced, many transactions were being carried out in dollars. Rather than forbid their use (doing so had proved futile in the past), the program made all contracts legal and fully enforceable in Argentina, whatever the currency they were written in. This freedom to choose the currency to be used in any transaction has dramatic implications. In effect, the government has relinquished monopoly power over money. (...) Argentina does not really have an exchange rate. It has only an accounting rate that allows easy conversion between pesos and dollars" (Cavallo \& Mondino, 1996, p. 18, 19).

39 Sobre a crise mexicana ver, por exemplo, Sachs, Tornell \& Velasco (1995), Souza (1995) e Krugman (1995). A visão do FMI foi apresentada em International Monetary Fund, 1995, p. 53-79.

40 Banco Central do Brasil, jun.1996, p. 158.

41 Banco Central do Brasil, 15 ago. 1996, p.1. 
42 Instituto Brasileiro de Geografia e Estatística, 1996, p.11.

43 Banco Central do Brasil, Relatório 1994, p. 53, 61-62.

44 Banco Central do Brasil, ago.1995, p. 65.

45 Fundación Cedeal, fev. 1993, p. 27.

46 Comisión Económica para América Latina y el Caribe, 1989a, p. 58.

47 A tarifa média de importação aumentou de 11,3\% em dezembro de 1994 para 13,9\% em dezembro de 1995 (Universidade Federal do Rio de Janeiro, abr. 1996, p. 38).

48 Confederação Nacional da Indústria, 1996, p. 21. Depois de uma recuperação em março e abril de 1995, o índice da taxa efetiva de câmbio do real, calculado com base em índices de preços ao consumidor, declinou de forma gradual até o fim de 1995, estabilizando-se daí em diante. A valorização efetiva acumulada desde a introdução do real era de $32 \%$ em junho de 1996. Essa cesta de moedas é calculada com base na participação dos dez países nas pautas de exportação e importação brasileiras no período 1991-93 (Idem, ibidem). Estimativa do Instituto de Economia da Universidade Federal do Rio de Janeiro, aponta também para uma valorização real de $31 \%$ em termos efetivos, quando se compara a taxa de câmbio média do primeiro semestre de $1996 \mathrm{com}$ a do primeiro semestre de 1994, utilizando-se o INPC como indicador de inflação doméstica e índices de preços por atacado como indicadores de inflação externa (Universidade Federal do Rio de Janeiro, jul. 1996, p. 30).

49 Instituto Brasileiro de Geografia e Estatística, ago. 1996, p.11.

50 Banco Central do Brasil, jun. 1996, p.72.

51 A operação financeira de emergência, anunciada em fins de janeiro, incluía US\$ 20 bilhões dos EUA, US\$ 18 bilhões do FMI, US\$ 10 bilhões do Banco para Compensações Internacionais e US\$ 3 bilhões dos bancos comerciais. As negociações entre os governos norte-americano e mexicano foram concluídas em fins de fevereiro. Os empréstimos do Banco para Compensações Internacionais e dos bancos comerciais nunca chegaram a ser finalizados (International Monetary Fund, 1995, p. 63). Observe-se que a atuação do FMI nesse episódio provocou críticas severas. Não apenas porque o Fundo não antecipou a crise mexicana, mas também porque a sua participação na operação de salvamento implicou romper as regras existentes quanto aos limites de apoio financeiro. Uma ex-integrante do staff do FMI observou que a participação da instituição no pacote financeiro orquestrado pelo governo dos EUA "wholly undermined the supposedly rule-based nature of the IMF, and has been widely interpreted as an example of the IMF's increasing politicization" (Minton-Beddoes, 1995, p. 128).

52 Banco Central do Brasil, maio 1995, p. 43.

53 Banco Central do Brasil, set. 1995, p.188.

54 As receitas de exportação de petróleo passaram a ser depositadas diretamente pelos importadores em conta num banco americano (Banco Central do Brasil, abr. 1995, p. 36-37).

Estudos AvanÇados 10 (28), 1996 
55 Comisión Económica para América Latina y el Caribe, 1996, p. 59.

56 Organisation for Economic Co-operation and Development, 1996, p. A4. Em 1983, o PIB mexicano registrou queda de 4,2\% (Comisión Económica para América Latina y el Caribe, 1989b, p. 18).

57 Banco Central do Brasil, maio 1996, p. 40.

58 Entre julho de 1994 e abril de 1996, os empréstimos do sistema financeiro em atraso e em liquidação mais do que triplicaram, passando de R\$ 12,4 bilhões para R\$ 41,9 bilhões. Nesse período, as operações em atraso e em liquidação aumentaram de 7,6\% para $15,3 \%$ do total dos empréstimos do sistema financeiro (Banco Central do Brasil, jul. 1996, p. 93, 97). Os dados não incluem créditos em liquidação de três instituições financeiras. Em geral, o Banco Central considera créditos em atraso as operações vencidas há mais de 60 dias. Os céditos em liquidação são as operações vencidas há mais de 180 dias com garantias consideradas insuficientes e há mais de 360 dias com garantias suficientes (Idem, p. 92).

59 Banco Central do Brasil, 19 jul. 1996, Quadro XVI.

60 Idem, Quadro XIII.

61 Entre novembro de 1995 e junho de 1996, a liberação líquida de recursos por conta do PROER• alcançou R\$ 8,8 bilhões (Idem, Quadro IV).

62 O Banco Central atribui a diminuição do superávit primário em 1995 ao aumento dos gastos com pessoal e benefícios da previdência social. No caso das empresas estatais, a piora do resultado é debitada à queda real das tarifas públicas (Banco Central do Brasil, Relatório 1995, p. 72).

63 Por medida provisória, o salário mínimo e os benefícios previdenciários foram reajustados, respectivamente, em $12 \%$ e $15 \%$ a partir de maio de 1996 . Pela mesma medida provisória, revogou-se dispositivo que assegurava reajustes do salário mínimo em maio de cada ano e a data de reajuste dos benefícios da Previdência foi transferida de maio para junho (Banco Central do Brasil, jun. 1996, p. 16). Nos 12 meses até abril de 1996, a taxa de inflação, medida por índices de preços ao consumidor, ficou em torno de $20 \%$ ( Idem, p. 71-72).

64 Comisión Económica para América Latina y el Caribe, 1995c, p. 54. No caso do México, os dados referem-se ao setor público consolidado; no caso da Argentina, apenas ao setor público não-financeiro nacional, excluindo províncias e municípios (Idem, ibidem).

65 O prazo médio da dívida mobiliária em mercado, de responsabilidade do Tesouro Nacional, oscilou entre dois e cinco meses em 1995 e no primeiro semestre de 1996 (Secretaria do Tesouro Nacional, 1996, p. 6-7).

66 Nos 12 meses até junho de 1995, a taxa de inflação brasileira, medida pelo INPC do IBGE, caiu para 33,4\%. No segundo ano do Plano Real, nos 12 meses até junho de 1996, a variação do INPC diminuiu ainda mais, para 16,3\% (Fundação Getúlio Vargas, set. 1996, conjuntura estatística, p.3). Nos dois primeiros anos do programa mexica- 
no, 1988 e 1989, a taxa de inflação, medida por um índice de preços ao consumidor, foi de 51,7\% e 19,7\%, respectivamente (Comisión Económica para América Latina y el Caribe, 1994, p. 43).

67 No primeiro ano do programa de conversibilidade argentino, entre abril de 1991 e março de 1992, a taxa de inflação ao consumidor foi de 30,2\%. No segundo ano, até março de 1993, a taxa de inflação caiu para 12\% (Fundación Cedeal, fev. 1993, p. 27; ago. 1993, p. 19).

68 Note-se que a dívida externa pública (líquida de reservas internacionais) representava, em maio de 1996, apenas 4,4\% do PIB e 13,3\% da dívida líquida do setor público (Banco Central do Brasil, ago. 1996, p. 134). Ao contrário do que ocorria nos anos 80, uma desvalorização cambial real teria, portanto, efeito limitado em termos de aumento do serviço da dívida pública.

69 No quarto trimestre de 1995 e no primeiro de 1996, a série do PIB com ajuste sazonal indica crescimento anualizado de 5\% (Instituto Brasileiro de Geografia e Estatística, ago. 1996, p. 11).

70 Fundação Getúlio Vargas, set. 1996, conjuntura estatística, p. 10.

71 Instituto Brasileiro de Geografia e Estatística, jun. 1996, tabelas 2, 5.

72 Comisión Económica para América Latina y el Caribe, 1995c, p. 49, 51.

73 Fundação Getúlio Vargas, set. 1996, conjuntura estatística, p. $2,4$.

74 Idem, p. 17 e The Economist, July 20th 1996, p. 88.

75 Banco Central do Brasil, 19 set. 1996, Quadros IV e VIII.

76 Ver Sachs, Tornell \& Velasco (1995, p.12 e tabela 7a) e Organisation for Economic Co-operation and Development (1995, p. 19-21). Em 1994, o México acolheu mais de $50 \%$ do investimento direto estrangeiro realizado na América Latina e no Caribe. A OECD observa que os US\$ 8 bilhões de investimentos recebidos em 1994 eram considerados "a very positive development in the eyes of the Mexican authorities, since foreign direct investment is not subject to sudden shifts in investor sentiment, and hence is not volatile." Não obstante, ressalva o documento da OECD, "the size of portfolio investments over the past years created a situation of vulnerability to changes in financial markets' perceptions" (Idem, p. 21, 126).

77 Fundo Monetário Internacional, jun.1996, p. S426.

78 Universidade Federal do Rio de Janeiro, jul. 1996, p. 34, 37-38.

79 Banco Central do Brasil, jul.1996, p. 174.

Referências bibliográficas

I. Legislação, Documentos Oficiais e Fontes de Estatísticas.

AMERICAN Express Bank. Monthly Economics Report, Global Economics Unit, 2nd February 1995. 
BANCO Central do Brasil. Brasil Programa Econômico, v.14, fev. 1987.

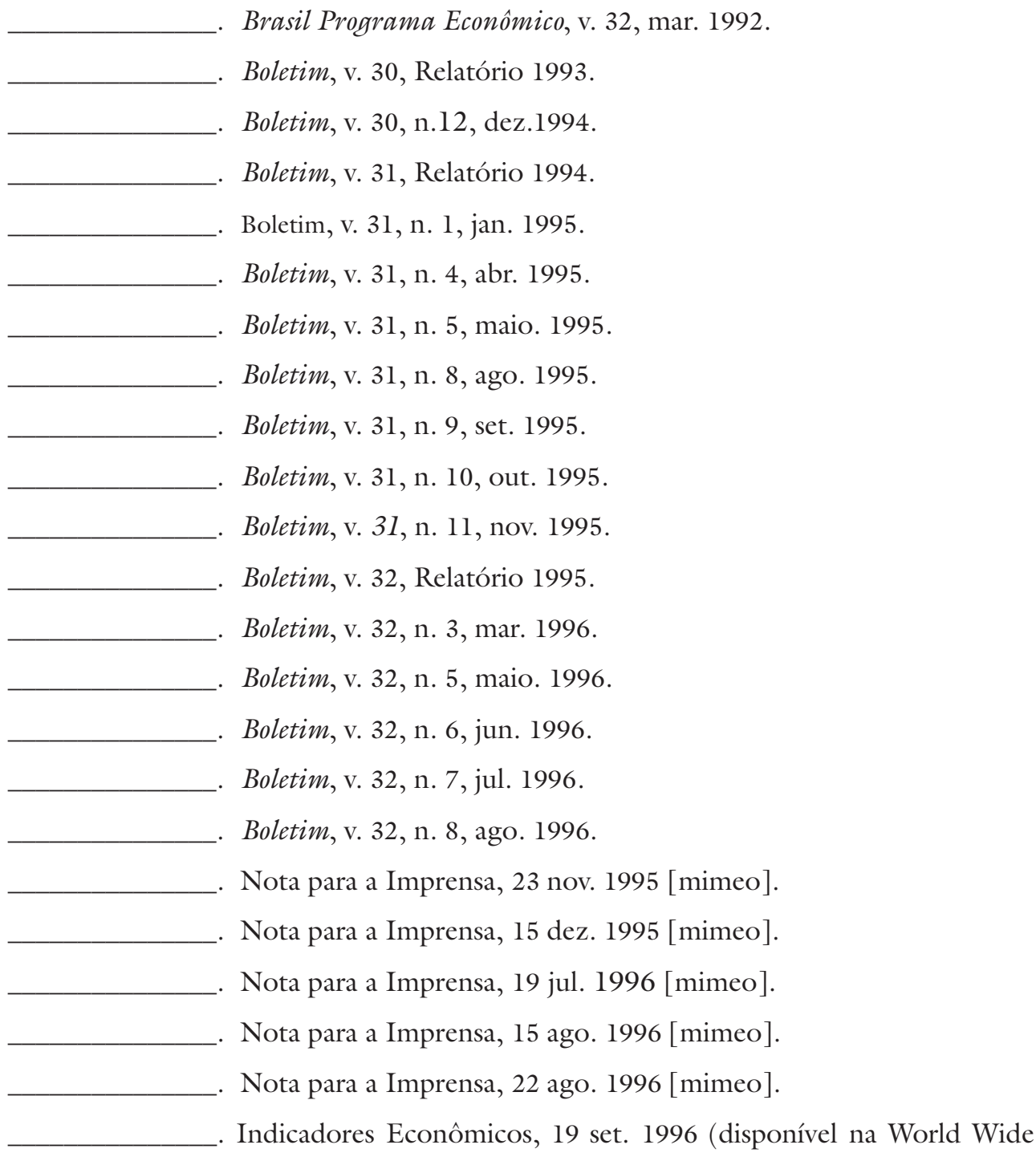
Web em: http://www.bcb.gov.br/htms/noteconl.)

BANCO Itaú S.A. Indicadores Econômicos, nov. 1995 [mimeo]. Indicadores Econômicos, ago. 1996 [mimeo].

COMISIÓN Económica para América Latina y el Caribe. Economic panorama of Latin America 1989. Santiago de Chile, United Nations, sept. 1989a.

Preliminary overview of the economy of Latin America and the Caribbean 1989. United Nations, 29 dec. 1989b.

Balance preliminar de la economia de América Latina y el Caribe 1993. Santiago de Chile, Naciones Unidas, 17 dic. 1993. 
Balance preliminar de la economia de América Latina y el Caribe 1994. Santiago de Chile, Naciones Unidas, 20 dic. 1994.

Panorama económico de América Latina 1995. Santiago de Chile, Naciones Unidas, 15 sept. 1995a.

Estudio económico de América Latina y el Caribe 1994-1995. Santiago de Chile, Naciones Unidas, 27 sept. 1995b.

Balance preliminar de la economia de América Latina y el Caribe 1995. Santiago de Chile, Naciones Unidas, dic. 1995c.

Panorama económico de América Latina 1996. Santiago de Chile, Naciones Unidas, 12 sept. 1996.

CONFEDERAÇÃO Nacional da Indústria. Informe Conjuntural, n.114, nov. 1995 [mimeo]. Informe Conjuntural, n. 121, jul. 1996 [mimeo].

FUNDAÇÃO Centro de Estudos do Comércio Exterior. Boletim Funcex de Câmbio, Ano VI, n. 6, jun. 1996 [mimeo].

FUNDAÇÃO Getúlio Vargas. Conjuntura Econômica, v. 49, n.11, nov. 1995. - Conjuntura Econômica, v. 49, n. 12, dez. 1995.

- Conjuntura Econômica, v. 50, n. 7, jul. 1996.

- Conjuntura Econômica, v. 50, n. 8, ago. 1996.

Conjuntura Econômica, v. 50, n. 9, set. 1996.

FUNDACIÓN Cedeal. Situación Latinoamericana. Madri, Año 3, n. 13, feb. 1993. . Situación Latinoamericana. Madri, Año 3, ago. 1993.

INSTITUTO Brasileiro de Geografia e Estatística. Indicadores IBGE - Pesquisa Mensal de Emprego, jun. 1996 [mimeo].

Indicadores do IBGE - Produto Interno Bruto Trimestral, $2^{\circ}$ trimestre de 1996, ago. 1996 [mimeo].

INTERNATIONAL Monetary Fund. Estadisticas financieras internacionales, dic. 1993. Estadisticas financieras internacionales, jun. 1996. Estadisticas financieras internacionales: anuario, 1994.

International capital markets - developments, prospects, and policy issues, aug. 1995.

MINISTÉRIO da Fazenda. Programa de Estabilização - Exposição de Motivos n ${ }^{\circ} 395$, de 7 de dezembro de 1993. Brasília, 1993 [mimeo]. 
ORGANISATION for Economic Co-operation and Development. OECD economic surveys: Mexico 1995. Paris, July 1995.

OECD Economic outlook 59. Paris, June 1996.

PRESIDÊNCIA da República. Mensagem no 55, de 1994-CN. Brasília, 27 de fevereiro de 1994a (encaminhando medida provisória que criou a URV, acompanhada de exposição de motivos).

Medida Provisória n ${ }^{\circ}$ 542, de 30 de junho de 1994, Brasília: Diário Oficial, 1994b (medida provisória que criou o real, acompanhada de exposição de motivos).

SECRETARIA do Tesouro Nacional. Resultado do Tesouro Nacional, v. 2, n. 7, jul. 1996.

THE ECONOMIST Newspaper Limited. The Economist, vários números.

UNIVERSIDADE Federal do Rio de Janeiro. Boletim de Conjuntura. Publicação do Instituto de Economia, v.16, n.1, abr. 1996.

Boletim de Conjuntura, v.16, n.2, jul. 1996.

\section{Livros e Artigos.}

BACHA, Edmar. O fisco e a inflação: uma interpretação do caso brasileiro. Revista de Economia Política, v.14, n.1, jan./mar. 1994.

BATISTA, Paulo Nogueira. O Consenso de Washington: a visão neoliberal dos problemas latino-americanos. Programa Educativo Dívida Externa - PEDEX, Caderno Dívida Externa, n. 6, 2. ed., nov. 1994.

BATISTA JR., Paulo Nogueira. Hiperinflação, ajuste fiscal e regressão monetária. Novos Estudos Cebrap, n. 36, jul. 1993a.

Dolarização, âncora cambial e reservas internacionais. Revista de Economia Politica, v.13, n.3, jul./set. 1993b.

1993c. A armadilha da dolarização. Estudos Econômicos, v.23, n.3, set./dez.

BATISTA JR., Paulo Nogueira \& RANGEL, Armênio de Souza. A renegociação da divida externa brasileira e o Plano Brady: avaliação de alguns dos principais resultados. Programa Educativo Dívida Externa - PEDEX, Caderno Dívida Externa, n. 7, out. 1994.

BLAUG, Mark. The methodology of economics. Cambridge, Cambridge University Press, 1980.

BUCHANAN, James M.; WAGNER, R.E. \& BURTON, John. The consequences of Mr Keynes. In: James Buchanan, Constitutional economics. Oxford, Basil Blackwell, 1991. 
CARVALHO, Fernando J. Cardim de. Estabilização, ancoragem de preços e política de rendas. Novos Estudos CEBR AP, n.41, mar. 1995.

CAVALLO, Domingo F. \& MONDINO, Guillermo. Argentina's miracle? From hyperinflation to sustained growth. In: Michael Bruno \& Boris Pleskovic (eds.), ANNUAL WORLD BANK CONFERENCE ON DEVELOPMENT ECONOMICS 1995. Washington, D.C., The World Bank, 1996.

CORDEN, W. Max. Economic policy, exchange rates and the international system. Oxford, Oxford Universty Press, 1994.

FARIA, Lauro Vieira de. Brasil: campeão da usura. Conjuntura Econômica, v. 48, n. 4, abr. 1994.

FFRENCH-DAVIS, Ricardo; AGOSIN, Manuel \& UTHOFF, Andras. Movimientos de capitales, estrategia exportadora y estabilidad macroeconómica en Chile. CEPAL e NorthSouth Institute de Ottawa, 1995 [mimeo].

FISCHER, Stanley. Modern central banking. In: Forrest Capie, Charles Goodhart; Stanley Fischer \& Norbert Schnadt (orgs.). The future of central banking. THE TERCENTENARY SYMPOSIUM OF THE BANK OF ENGLAND, Cambridge: Cambridge University Press, 1994.

GOODHART. Charles A. E. The central bank and the financial system. London, MacMillan Press, 1995.

HOMMES, Rudolf. Nuevos desafios para América Latina. FORO INTERNACIONAL: CRISIS FINANCIERA Y POLITICAS DE AJUSTE EN AMÉRICA LATINA. Parlamento Latinoamericano, Cuadernos del Parlatino n.7, 17 feb. 1995.

KEYNES, John Maynard. A treatise on money: volume 1-The pure theory of money. 1. ed.: 1930; republicado in: The collected writings of John Maynard Keynes, v. v. Cambridge, Cambridge University Press for the Royal Economic Society, 1971.

A treatise on money: volume 2 - The applied theory of money, 1. ed.: 1930; republicado in: The collected writings of John Maynard Keynes, v. VI. Cambridge, Cambridge University Press for the Royal Economic Society, 1971.

KRUGMAN, Paul. Dutch tulips and emerging markets. Foreign Affairs, v. 74, n. 4, July/Aug. 1995.

LUTHER, Hans. Die Stabilisierung der deutschen Währung: Aus persönlichen Erinnerungen erzählt. In: Hermann Müller (org.), Zehn Jahre Deutsche Geschichte, 1918-1928. Berlin, Otto Stolberg Verlag, 1928.

McKINNON, Ronald. Discussion of a paper by Peter B.Kenen. In: Peter B. Kenen, Francesco Papadia and Fabrizio Saccomani (orgs.), The international monetary sytem. PROCEEDINGS OF A CONFERENCE ORGANIZED BY THE BANCA D'ITALIA. Cambridge: Cambridge University Press, 1994.

MINTON-BEDDOES, Zanny. Why the IMF needs reform. Foreign Affairs, v. 74, n. 3, May/June 1995. 
POPPER, Karl R. The logic of scientific discovery. London, Hutchisnson \& Co (publishers) Ltd., 1959.

SACHS, Jeffrey; TORNELL, Aaron \& VELASCO, Andrés. The collapse of the Mexican peso: what have we learned? National Bureau of Economic Resesearch, Working Paper n. 5142, June 1995 [mimeo].

SARGENT,Thomas J. Rational expectations and inflation. New York, Harper \& Row, Publishers, 1986.

SOUZA, Francisco E. Pires de. Fundamentos econômicos da crise do peso. Politica Externa, v. 4, n. 1, jun. 1995.

RESUMO - O trabalho discute os primeiros dois anos do Plano Real e em especial os seus efeitos sobre as relações externas do Brasil, à luz da experiência de programas de estabilização adotados no México, em 1988-1994, e na Argentina, desde 1991. Embora cada experiência nacional apresente as suas peculiaridades, argumenta-se que a economia brasileira vem revivendo a experiência mexicana e argentina em alguns pontos importantes, combinando sucesso no combate à inflação com acentuada e persistente apreciação cambial, elevados déficits no balanço de pagamentos em conta corrente e dependência de fluxos voláteis de capital internacional.

ABSTRACT - This paper discusses the first two years of Brazil's current stabilization programme - known as the Real Plan - and in particular its effects on the country's external economic relations, in the ligth of similar stabilization programmes adopted in Mexico from 1988 to 1994 and in Argentina since 1991. Although each national experience has its peculiarities, it is shown that the Brazilian economy has been reliving the Mexican and Argentinian experience in some important respects, combining success in terms of inflation reduction, with strong and persistent exchange rate appreciation, high deficits in the balance of payments on current account and dependence on volatile international capital flows.

Paulo Nogueira Batista Jr. é pesquisador-visitante do Instituto de Estudos Avançados da Universidade de São Paulo.

Trabalho concluído em setembro de 1996. Carolina Moretti Fonseca e Alessandra S. Henrique das Almeida auxiliaram no levantamento de informações e na elaboração de tabelas. Preparação de Hermínia Antonia G. Bernardini. Tabelas formatadas por Sandra A. M. Guiral. O autor agradece a Juan José Pereira, da Divisão de Desenvolvimento Econômico da Comissão Econômica para a América Latina e o Caribe (CEPAL), pela ajuda na obtenção de estatísticas e por esclarecimentos a respeito das mesmas. 
Tabela 1

Balanço de pagamentos do Brasil, 1992-95

(Principais Contas)

(Em milhões de US\$)

\begin{tabular}{|c|c|c|c|c|}
\hline & 1992 & 1993 & 1994 & $1995^{\star}$ \\
\hline 1. Balança Comercial & 15.239 & 13.307 & 10.466 & -3.157 \\
\hline Exportações (FOB) & 35.793 & 38.563 & 43.545 & 46.506 \\
\hline Importações (FOB) & -20.554 & -25.256 & -33.079 & -49.663 \\
\hline 2. Serviços & -11.339 & -15.585 & -14.743 & -18.600 \\
\hline Juros (liq.) & -7.253 & -8.280 & -6.338 & -8.158 \\
\hline Lucros e Dividendos (líq.) ${ }^{\star \star}$ & -749 & -1.931 & -2.566 & -2.790 \\
\hline Viagens Internacionais (liq.) & -319 & -799 & -1.181 & -2.419 \\
\hline Transportes (liq.) & -1.359 & -2.090 & -2.441 & -3.200 \\
\hline Outros Serviços (liq.) & -1.659 & -2.485 & -2.217 & -2.033 \\
\hline 3. Transferências Unilaterais (líq.) & 2.243 & 1.686 & 2.588 & 3.973 \\
\hline 4. Saldo em Conta Corrente $(1+2+3)$ & 6.143 & -592 & -1.689 & -17.784 \\
\hline 5. Capital ${ }^{\star \star}$ & 25.271 & 10.115 & 14.294 & 29.820 \\
\hline Amortizações Pagas & -7.147 & -9.268 & -11.001 & -11.026 \\
\hline 6. Erros e Omissões & -1.386 & -1.119 & 334 & 1.444 \\
\hline 7. Resultado Global $(4+5+6)$ & 30.028 & 8.404 & 12.939 & 13.480 \\
\hline 8. Financiamento & -30.028 & -8.404 & -12.939 & -13.480 \\
\hline Haveres (- = aumento) & -14.670 & -8.709 & -7.215 & -12.919 \\
\hline Obrigações — FMI & -406 & -495 & -129 & -47 \\
\hline Obrigações de curto prazo & -14.952 & 800 & -5.595 & -514 \\
\hline Atrasados & -14.253 & 1.133 & -5.653 & -510 \\
\hline Outras & -699 & -333 & 58 & -4 \\
\hline
\end{tabular}

$(*)$ Dados preliminares; $\left({ }^{* *}\right)$ Inclui lucros reinvestidos.

Fonte: Banco Central do Brasil.

Estudos AvAnÇADOS 10 (28), 1996 
Tabela 2

Países selecionados da América Latina: déficit em conta corrente como proporção das exportações de bens (FOB), 1992-95

\begin{tabular}{lrrrr} 
& & & Em \% \\
\hline & 1992 & 1993 & 1994 & $1995^{\star}$ \\
Argentina & 54,5 & 53,7 & 59,1 & 11,4 \\
Brasil & $-17,2$ & 1,5 & 3,9 & 38,2 \\
Chile & 9,4 & 22,8 & 5,5 & $-1,0$ \\
Colômbia & $-12,7$ & 28,7 & 34,6 & 39,0 \\
México & 88,7 & 78,0 & 83,2 & $0,8^{\star \star}$ \\
\hline
\end{tabular}

(*) Dados preliminares; $\left({ }^{* *}\right)$ Inclui exportações de maquiladoras.

Fontes: Banco Central do Brasil, Comissão Econômica para América Latina e o Caribe (CEPAL) e Organização para a Cooperação e Desenvolvimento Econômico (OCDE). 
Tabela 3

Reservas internacionais no Banco Central do Brasil, 1985-95

\begin{tabular}{|c|c|c|c|}
\hline \multirow[b]{2}{*}{ Período } & & \multicolumn{2}{|c|}{ Conceito de caixa* } \\
\hline & & Em US\$ milhões & $\begin{array}{c}\text { Em meses de } \\
\text { importação de bens }\end{array}$ \\
\hline 1985 & & 7.690 & 7 \\
\hline 1986 & & 4.585 & 4 \\
\hline 1987 & & 4.433 & 4 \\
\hline 1988 & & 5.359 & 4 \\
\hline 1989 & & 7.268 & 5 \\
\hline 1990 & & 8.751 & 5 \\
\hline 1991 & & 8.552 & 5 \\
\hline 1992 & & 19.008 & 11 \\
\hline 1993 & & 25.878 & 12 \\
\hline \multirow[t]{12}{*}{1994} & Jan. & 29.138 & 14 \\
\hline & Fev. & 30.525 & 14 \\
\hline & Mar. & 32.295 & 15 \\
\hline & Abr. & 35.082 & 16 \\
\hline & Mai. & 38.270 & 17 \\
\hline & Jun. & 40.131 & 18 \\
\hline & Jul. & 40.317 & 18 \\
\hline & Ago. & 40.204 & 18 \\
\hline & Set. & 40.873 & 18 \\
\hline & Out. & 40.441 & 17 \\
\hline & Nov. & 39.531 & 15 \\
\hline & Dez. & 36.471 & 13 \\
\hline \multirow[t]{12}{*}{1995} & Jan. & 35.929 & 12 \\
\hline & Fev. & 35.750 & 12 \\
\hline & Mar. & 31.530 & 10 \\
\hline & Abr. & 29.918 & 9 \\
\hline & Mai. & 31.664 & 9 \\
\hline & Jun. & 31.492 & 8 \\
\hline & Jul. & 39.780 & 10 \\
\hline & Ago. & 45.776 & 11 \\
\hline & Set. & 46.614 & 11 \\
\hline & Out. & 48.231 & 11 \\
\hline & Nov. & 49.797 & 12 \\
\hline & Dez. & 50.449 & 12 \\
\hline \multirow[t]{6}{*}{1996} & Jan. & 52.176 & 13 \\
\hline & Fev. & 54.411 & 13 \\
\hline & Mar. & 54.331 & 13 \\
\hline & Abr. & 55.429 & 14 \\
\hline & Mai. & 58.058 & 15 \\
\hline & Jun. & 58.639 & 15 \\
\hline
\end{tabular}

(*) Conceito operacional do Banco Central, contemplando haveres prontamente disponíveis. Saldos em fim de período.

Fonte: Banco Central do Brasil. 
Tabela 4

Brasil: movimento de capitais, 1992-95

\begin{tabular}{|c|c|c|c|c|}
\hline Discriminação* & 1992 & 1993 & 1994 & 1995 \\
\hline Total & 25.271 & 10.115 & 14.294 & 29.820 \\
\hline Investimentos & 2.972 & 6.170 & 8.131 & 4.670 \\
\hline Brasileiros & -137 & -1.094 & -1.037 & -1.552 \\
\hline Estrangeiros & 3.109 & 7.264 & 9.168 & 6.222 \\
\hline Portfólios & 1.704 & 6.650 & 7.280 & 2.294 \\
\hline Diretos ${ }^{\star \star}$ & 1.405 & 614 & 1.888 & 3.928 \\
\hline Reinvestimentos & 175 & 100 & 83 & 200 \\
\hline \multicolumn{5}{|l|}{ Empréstimos e financiamentos a } \\
\hline médio e longos prazos & 19.661 & 3.192 & 4.421 & 6.351 \\
\hline Brasileiros & 67 & -245 & -450 & -846 \\
\hline Estrangeiros & 19.594 & 3.437 & 4.871 & 7.197 \\
\hline Organismos internacionais & -636 & -699 & -668 & -155 \\
\hline Agências governamentais & 9.061 & -291 & -691 & -1.644 \\
\hline Créditos de fornecedores e compradores & -1.692 & -906 & -548 & -428 \\
\hline Bônus & 780 & 101 & -280 & 1.190 \\
\hline 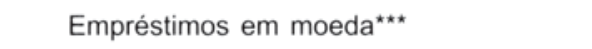 & 12.085 & 5.236 & 7.062 & 8.237 \\
\hline Demais & -4 & -4 & -4 & -3 \\
\hline Capitais a curto prazo & 2.602 & 869 & 909 & 19.667 \\
\hline Outros capitais & -139 & -216 & 750 & -1.068 \\
\hline
\end{tabular}

(*) Saldos liquidos; $(* *)$ Inclui investimentos em mercadorias e conversões; $\left({ }^{* * *}\right)$ Inclui refinanciamentos.

Fonte: Banco Central do Brasil. 


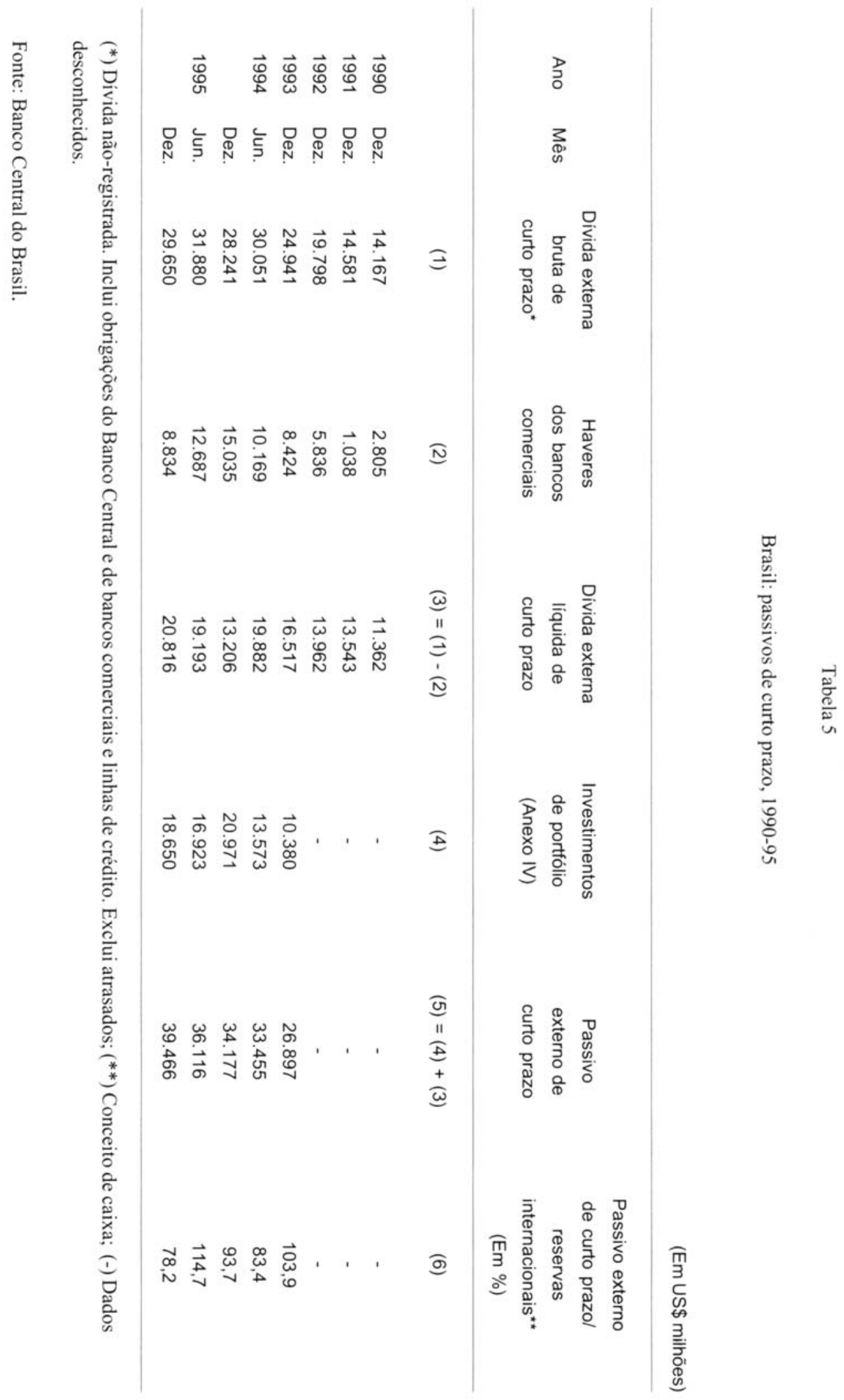

Estudos AvançAdos 10 (28), 1996 
Tabela 6

Brasil: carteira de ativos de investidores institucionais estrangeiros, 1993-96*

(Anexo IV da Resolução nำ1289/87)

\begin{tabular}{|c|c|c|c|c|c|c|c|}
\hline \multirow[b]{2}{*}{ Ano } & \multirow[b]{2}{*}{ Mês } & \multirow{2}{*}{$\begin{array}{c}\text { Estoque } \\
\text { de ativos }{ }^{\star \star} \\
(\text { Em US\$ milhões) }\end{array}$} & \multicolumn{5}{|c|}{ Composição da carteira (em \%) } \\
\hline & & & Ações & Derivativos & Debêntures & $\begin{array}{l}\text { Moedas de } \\
\text { Privatização }\end{array}$ & Outros \\
\hline \multirow[t]{2}{*}{1993} & Jun. & 4.834 & 82,6 & 0,0 & 2,7 & 0,1 & 14,6 \\
\hline & Dez. & 10.380 & 80,1 & 0,0 & 18,5 & 1,1 & 0,3 \\
\hline \multirow[t]{4}{*}{1994} & Mar. & 14.507 & 78,3 & 4,9 & 13,3 & 3,4 & 0,1 \\
\hline & Jun. & 13.573 & 66,7 & 8,6 & 15,1 & 9,5 & 0,1 \\
\hline & Set. & 21.612 & 78,1 & 3,2 & 12,3 & 5,0 & 1,4 \\
\hline & Dez. & 20.971 & 77,5 & 3,9 & 12,4 & 5,4 & 0,8 \\
\hline \multirow[t]{4}{*}{1995} & Mar. & 13.297 & 82,8 & 1,4 & 8,4 & 4,3 & 3,1 \\
\hline & Jun. & 16.923 & 85,2 & 2,1 & 7,6 & 4,4 & 0,7 \\
\hline & Set. & 19.751 & 86,4 & 3,0 & 6,0 & 4,1 & 0,5 \\
\hline & Dez. & 18.650 & 89,5 & 1,1 & 5,5 & 3,7 & 0,2 \\
\hline \multirow[t]{6}{*}{1996} & Jan. & 20.745 & 90,9 & 0,0 & 4,7 & 3,5 & 0,9 \\
\hline & Fev. & 20.657 & 90,3 & 0,1 & 4,5 & 4,1 & 1,0 \\
\hline & Mar. & 19.503 & 89,8 & 0,1 & 4,8 & 4,3 & 1,0 \\
\hline & Abr. & 19.922 & 89,2 & 0,1 & 5,8 & 3,9 & 1,0 \\
\hline & Mai. & 21.243 & 90,1 & 0,0 & 5,4 & 3,5 & 1,0 \\
\hline & Jun. & 23.326 & 91,1 & 0,0 & 4,8 & 3,2 & 0,9 \\
\hline
\end{tabular}

$\left(^{*}\right)$ Dados da Comissão de Valores Mobiliários; $\left(^{* *}\right)$ Saldos apurados em fim de período.

Fonte: Banco Central do Brasil. 
Tabela 7

Paises selecionados da América Latina:

divida bancária de curto prazo e reservas internacionais em junho de 1994

\begin{tabular}{|c|c|c|c|c|}
\hline \multirow[b]{2}{*}{ Paises } & \multicolumn{2}{|c|}{ Divida bancária de curto prazo ${ }^{(1)}$} & \multicolumn{2}{|c|}{ Reservas internacionais ${ }^{(2)}$} \\
\hline & $\begin{array}{c}\text { Como } \% \text { da divida } \\
\text { bancária total }\end{array}$ & $\begin{array}{l}\text { Como \% das } \\
\text { importações }\end{array}$ & $\begin{array}{c}\text { Em bilhões } \\
\text { de US\$ }\end{array}$ & $\begin{array}{l}\text { Em meses de } \\
\text { importação }^{(3)}\end{array}$ \\
\hline Argentina & 56,6 & 79,0 & 14,9 & 9,8 \\
\hline Brasil & 55,3 & 91,3 & 42,6 & 18,8 \\
\hline Chile & 52,1 & 46,5 & 11,4 & 13,3 \\
\hline Colômbia & 45,6 & 32,7 & 7,8 & $9,4^{(4)}$ \\
\hline México & 59,8 & $54,4^{(5)}$ & $16,5^{(6)}$ & $2,8^{(7)}$ \\
\hline Venezuela & 29,2 & 50,4 & 8,9 & 11,4 \\
\hline
\end{tabular}

(1) Inclui obrigações de curto prazo e dívidas de médio e longo prazos, com prazo remanescente de até um ano; (2) Liquidez internacional. Inclui divisas, direitos especiais de saque, posição de reservas no FMI e ouro (valorização nacional). (3) Considera-se a média mensal das importações FOB do período de julho de 1993 a junho de 1994; (4) Considera-se a média mensal do primeiro semestre de 1994; (5) Inclui tesobonos (títulos públicos indexados ao dólar); (6) Exclui ouro; (7) Exclui importações das empresas maquiladoras.

Fontes: American Express Bank e Fundo Monetário Internacional.

Tabela 8

Países selecionados da América Latina:

taxa de câmbio real efetiva para as exportações*

\begin{tabular}{lrrrrrrrr}
\hline & 1988 & 1989 & 1990 & 1991 & 1992 & 1993 & 1994 & 1995 \\
\hline Argentina & 106 & 117 & 82 & 68 & 63 & 60 & 64 & 71 \\
Brasil & 91 & 69 & 64 & 76 & 81 & 75 & 59 & 45 \\
Chile & 106 & 100 & 104 & 103 & 99 & 100 & 100 & 96 \\
Colômbia & 102 & 104 & 117 & 119 & 106 & 102 & 88 & 88 \\
México & 81 & 76 & 74 & 67 & 62 & 59 & 61 & 90 \\
\hline
\end{tabular}

${ }^{*}$ ) Corresponde à média dos indices de câmbio real da moeda de cada país em relação às moedas dos seus principais parceiros comerciais, ponderados pela importância relativa das exportações para esses parceiros. As ponderações correspondem à média do periodo 1989-93. Os índices foram elaborados com base em índices de preços ao consumidor. Base: $1987=100$.

Fonte: Comissão Econômica para América Latina e o Caribe.

Estudos AvanÇAdos 10 (28), 1996 
Tabela 9

Participação das exportações do Brasil nas exportações mundiais e nas exportações dos países em desenvolvimento, 1980-95

\begin{tabular}{cccc}
\hline Ano & $\begin{array}{c}\text { Exportações do Brasil/ } \\
\text { exportações mundiais }\end{array}$ & $\begin{array}{c}\text { Exportações do Brasil/ } \\
\text { exportações dos paises } \\
\text { em desenvolvimento }\end{array}$ & $\begin{array}{c}\text { Exportações do Brasil/ } \\
\text { exportações dos paises } \\
\text { em des. não-exportadores } \\
\text { de petróleo } \\
(\text { Em \%) }\end{array}$ \\
\hline 1980 & 1,06 & $($ Em \%) & 5,49 \\
1981 & 1,24 & 3,19 & 6,15 \\
1982 & 1,16 & 3,69 & 5,54 \\
1983 & 1,29 & 3,58 & 5,83 \\
1984 & 1,50 & 4,10 & 6,54 \\
1985 & 1,41 & 4,82 & 6,35 \\
1986 & 1,12 & 4,77 & 5,31 \\
1987 & 1,11 & 4,38 & 5,12 \\
1988 & 1,25 & 4,25 & 5,58 \\
1989 & 1,17 & 4,76 & 5,14 \\
1990 & 0,93 & 4,32 & 4,29 \\
1991 & 0,89 & 3,50 & 3,92 \\
1992 & 0,94 & 2,97 & 4,05 \\
1993 & 1,01 & 3,10 & 4,04 \\
1994 & 1,00 & 3,11 & 3,81 \\
1995 & 0,89 & 2,99 & 3,32 \\
\hline & & 2,59 & \\
\hline
\end{tabular}

Fonte: Fundo Monetário Internacional. 


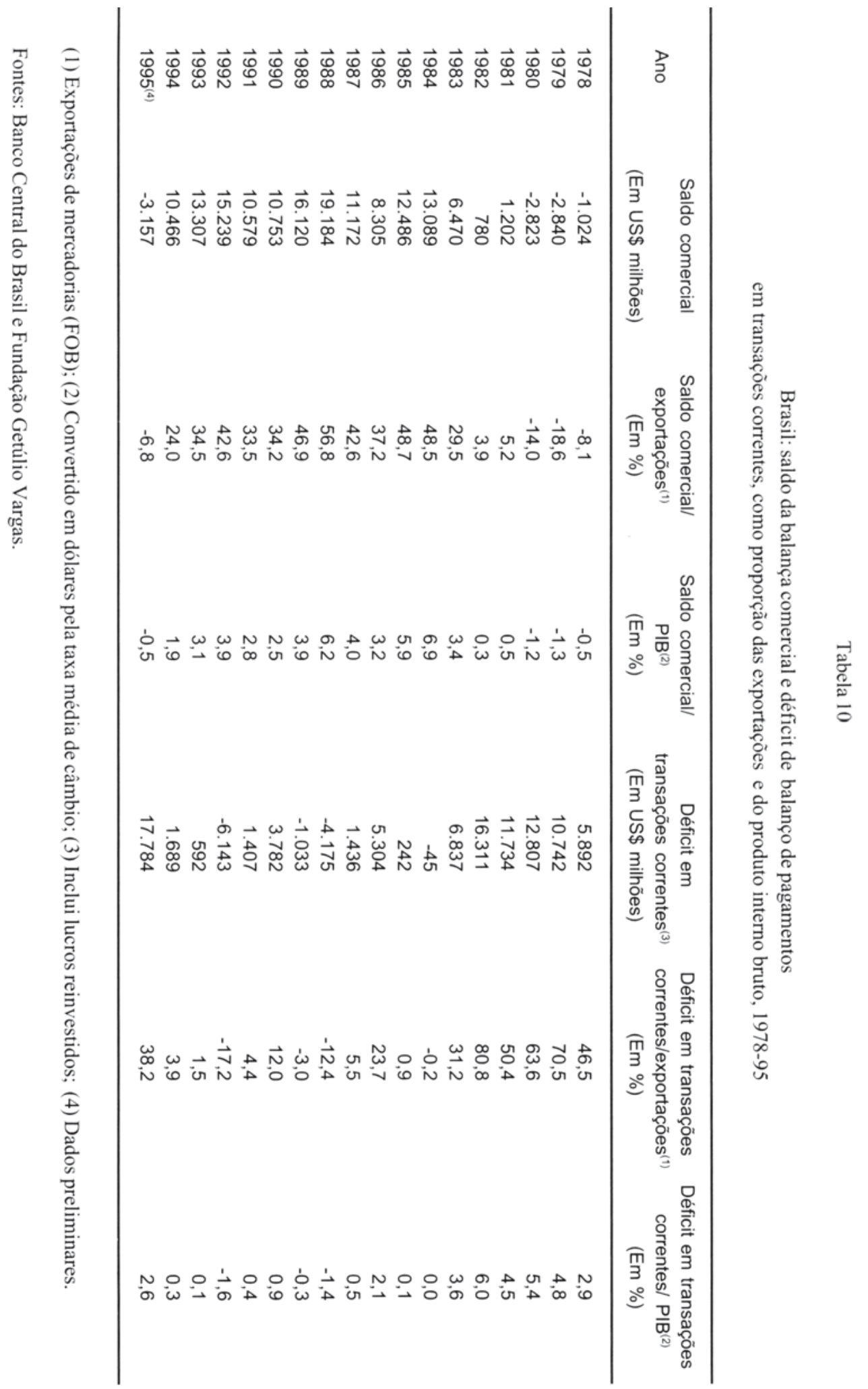

Estudos AvançAdos 10 (28), 1996 
Tabela 11

Evolução da taxa de câmbio do real com o dólar, 1994-96

\begin{tabular}{|c|c|c|c|c|c|}
\hline \multicolumn{2}{|c|}{ Periodo } & \multirow{2}{*}{$\begin{array}{c}\text { Taxa de câmbio* } \\
390,83\end{array}$} & \multirow{2}{*}{$\begin{array}{c}\text { Variação mensal } \\
\text { da taxa de câmbio } \\
(\text { Em \%) } \\
39,90\end{array}$} & \multirow{2}{*}{$\begin{array}{c}\text { Índice da taxa } \\
\text { de câmbio real } \\
\text { (INPC) } \\
95,28\end{array}$} & \multirow{2}{*}{$\begin{array}{c}\text { Índice da taxa } \\
\text { de câmbio real***} \\
\text { (IPA-DI) } \\
88,04\end{array}$} \\
\hline 1994 & Jan. & & & & \\
\hline & Fev. & 550,79 & 40,93 & 95,86 & 86,71 \\
\hline & Mar. & 768,11 & 39,46 & 93,77 & 84,59 \\
\hline & Abr. & $1.109,55$ & 44,45 & 94,90 & 87,24 \\
\hline & Mai. & $1.585,46$ & 42,89 & 95,09 & 90,02 \\
\hline & Jun. & $2.289,67$ & 44,42 & 92,97 & 89,78 \\
\hline & Jul. & 0,93 & 11,10 & 78,18 & 81,10 \\
\hline & Ago. & 0,90 & $-3,03$ & 74,70 & 75,76 \\
\hline & Set. & 0,86 & $-3,79$ & 71,07 & 71,40 \\
\hline & Out. & 0,84 & $-2,20$ & 67,65 & 67,99 \\
\hline & Nov. & 0,84 & $-0,47$ & 65,51 & 66,54 \\
\hline & Dez. & 0,85 & 0,95 & 65,03 & 67,25 \\
\hline \multirow[t]{12}{*}{1995} & Jan. & 0,85 & $-0,35$ & 64,10 & 66,88 \\
\hline & Fev. & 0,84 & $-0,71$ & 63,29 & 66,46 \\
\hline & Mar. & 0,89 & 5,72 & 66,07 & 69,64 \\
\hline & Abr. & 0,91 & 2,14 & 66,07 & 70,27 \\
\hline & Mai. & 0,90 & $-1,21$ & 64,04 & 71,05 \\
\hline & Jun. & 0,91 & 1,90 & 63,97 & 71,50 \\
\hline & Jul. & 0,93 & 1,64 & 63,46 & 71,08 \\
\hline & Ago. & 0,94 & 1,40 & 63,86 & 70,66 \\
\hline & Set. & 0,95 & 1,17 & 64,03 & 73,39 \\
\hline & Out. & 0,96 & 0,84 & 63,84 & 73,98 \\
\hline & Nov. & 0,96 & 0,42 & 63,15 & 73,40 \\
\hline & Dez. & 0,97 & 0,42 & 62,33 & 74,36 \\
\hline \multirow[t]{6}{*}{1996} & Jan. & 0,97 & 0,67 & 62,22 & 74,17 \\
\hline & Fev. & 0,98 & 0,68 & 62,41 & 74,18 \\
\hline & Mar. & 0,99 & 0,53 & 62,87 & 74,90 \\
\hline & Abr. & 0,99 & 0,42 & 62,76 & 75,60 \\
\hline & Mai. & 0,99 & 0,52 & 62,44 & 75,39 \\
\hline & Jun. & 1,00 & 0,61 & 62,15 & 75,31 \\
\hline
\end{tabular}

(*) Taxa de câmbio comercial de compra. Média dos dados diários. De janeiro a junho de 1994, valores em cruzeiros reais. A partir de julho de 1994, valores em reais; $\left({ }^{* *}\right)$ Taxa de câmbio nominal ajustada pelo diferencial de inflação com os EUA. Deflatores: Brasil - INPC (Índice Nacional de Preços ao Consumidor); EUA - IPC (Índice de Preços ao Consumidor). Base: jan/92 =100. Em julho de 1994, foi usada a variação do IPC — FGV medido em cruzeiros reais; $\left({ }^{* * *}\right)$ Taxa de câmbio nominal ajustada pelo diferencial de inflação com os EUA. Deflatores: Brasil - IPA-DI (Índice de Preços por Atacado - Disponibilidade Interna); EUA — IPP (Índice de Preços ao Produtor). Base: $\mathrm{jan} / 92=100$.

Fontes: Dados brutos - Banco Central do Brasil, Fundo Monetário Internacional e jornais diários. 
Tabela 12

Brasil: relação câmbio/salário industrial, 1994-96

\begin{tabular}{|c|c|c|c|c|}
\hline Ano & Mês & $\begin{array}{c}\text { Índice do Salário Nominal } \\
\text { por Trabalhador }\end{array}$ & $\begin{array}{l}\text { Índice da Taxa de } \\
\text { Câmbio Nominal }{ }^{\star \star}\end{array}$ & $\begin{array}{c}\text { Índice da Relação } \\
\text { Câmbio/Salário }\end{array}$ \\
\hline \multirow[t]{3}{*}{1994} & Jun. & 100,00 & 100,00 & 100,00 \\
\hline & Set. & 107,57 & 103,65 & 96,36 \\
\hline & Dez. & 128,75 & 101,85 & 79,10 \\
\hline \multirow[t]{4}{*}{1995} & Mar. & 132,63 & 106,53 & 80,32 \\
\hline & Jun. & 145,77 & 109,54 & 75,14 \\
\hline & Set. & 148,49 & 114,22 & 76,92 \\
\hline & Dez. & 168,29 & 116,14 & 69,01 \\
\hline \multirow[t]{2}{*}{1996} & Mar. & 169,61 & 118,44 & 69,83 \\
\hline & Jun. & 174,37 & 120,22 & 68,95 \\
\hline
\end{tabular}

(*) Folha de pagamentos dividida pelo total de pessoas empregadas; $\left({ }^{* *}\right)$ Taxa de câmbio comercial de compra com o dólar dos EUA. Média dos dados diários.

Fontes: Dados brutos - Banco Central do Brasil, Confederação Nacional da Indústria e jornais diários. 


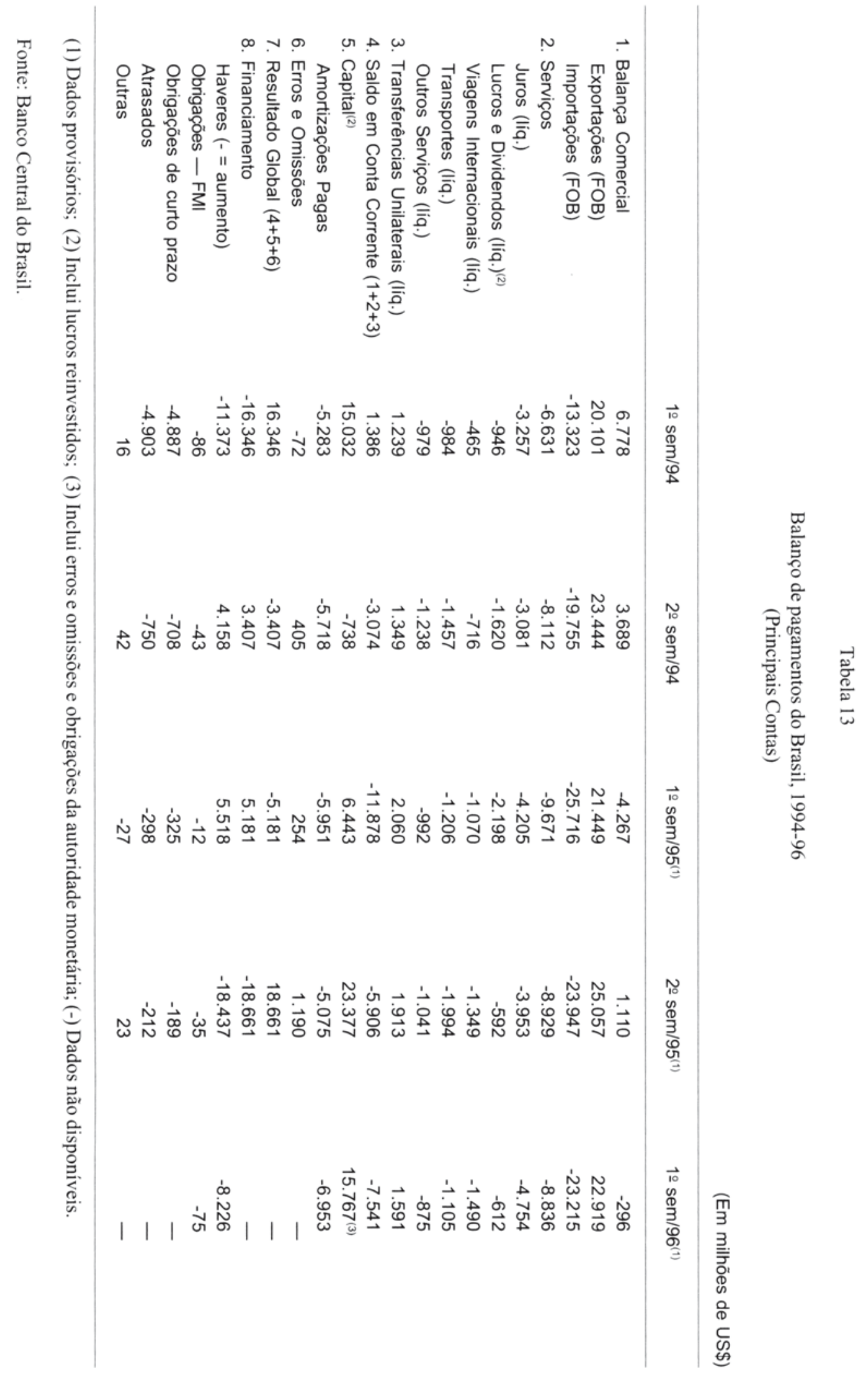


Tabela 14

Taxas de juro nos países do G-7

\begin{tabular}{lccc}
\hline \multicolumn{1}{c}{ Pais } & $\begin{array}{c}\text { Taxa de juro nominal } \\
(\% \text { a.a. })\end{array}$ & $\begin{array}{c}\text { Inflação** } \\
(\% \text { a.a. })\end{array}$ & $\begin{array}{c}\text { Taxa de juro real } \\
(\% \text { a.a. })\end{array}$ \\
& $(1)$ & $(2)$ & $(3)=(1) /(2)$ \\
Alemanha & 4,55 & 3,70 & 0,82 \\
Canadá & 7,34 & 4,20 & 3,01 \\
Estados Unidos & 6,02 & 4,10 & 1,84 \\
França & 7,05 & 2,90 & 4,03 \\
Itália & 10,13 & 7,80 & 2,16 \\
Japão & 1,35 & $-2,20$ & 3,63 \\
Reino Unido & 6,69 & 5,70 & 0,94 \\
\hline
\end{tabular}

(*) Meados de maio de 1995. Taxas para prazos de 3 meses no mercado monetário. (**) Índices de preços ao consumidor. Média do período fev./95 a abr./95 comparada com a média dos 3 meses precedentes, a taxas anualizadas. No caso do Canadá e Japão, média do período jan./95 a mar./95 comparada com a média dos 3 meses precedentes, a taxas anualizadas.

Fonte: Dados brutos - The Economist.

Tabela 15

Taxas de juro em outros países desenvolvidos

\begin{tabular}{lccc}
\hline Pais & $\begin{array}{c}\text { Taxa de juro nominal } \\
(\% \text { a.a. })\end{array}$ & $\begin{array}{c}\text { Inflação** } \\
(\% \text { a.a. })\end{array}$ & $\begin{array}{c}\text { Taxa de juro real } \\
(\% \text { a.a. })\end{array}$ \\
$(1)$ & $(2)$ & $(3)=(1) /(2)$ \\
Austrália & 7,70 & 6,90 & 0,75 \\
Áustria & 4,66 & 4,60 & 0,06 \\
Bélgica & 5,13 & 2,30 & 2,77 \\
Dinamarca & 6,65 & 2,10 & 4,46 \\
Espanha & 9,31 & 7,80 & 1,40 \\
Holanda & 4,50 & 3,80 & 0,67 \\
Suécia & 8,70 & 4,40 & 4,12 \\
Suiça & 3,38 & 6,00 & $-2,47$ \\
\hline
\end{tabular}

(*) Meados de maio de 1995. Taxas para prazos de 3 meses no mercado monetário; (**) Índices de preços ao consumidor. Média do período fev./95 a abr./95 comparada com a média dos 3 meses precedentes, a taxas anualizadas. No caso da Austrália, Áustria e Dinamarca, média do período jan./95 a mar./95 comparada com a média dos 3 meses precedentes, a taxas anualizadas.

Fonte: Dados brutos - The Economist. 
Tabela 16

Taxas de juros em países selecionados da África,

Ásia, América Latina e Europa Oriental

\begin{tabular}{|c|c|c|c|}
\hline Pais & $\begin{array}{l}\text { Taxa de juro nominal }{ }^{1} \\
\text { (\% a.a.) } \\
\text { (1) }\end{array}$ & $\begin{array}{c}\text { Inflação }{ }^{2} \\
\text { (\% a.a.) } \\
(2)\end{array}$ & $\begin{array}{c}\text { Taxa de juro real } \\
(\% \text { a.a. }) \\
(3)=(1) /(2)\end{array}$ \\
\hline África do Sul & 14,35 & 10,66 mar. & 3,34 \\
\hline Argentina & 21,20 & $-0,49 \mathrm{abr}$ & 21,79 \\
\hline Brasil & 64,80 & $22,49^{*}$ abr. & 34,54 \\
\hline Chile & 12,68 & 6,46 abr. & 5,84 \\
\hline Cingapura & 1,50 & $-2,40$ mar. & 4,00 \\
\hline Coréia do Sul & 15,20 & $9,71 \mathrm{abr}$ & 5,00 \\
\hline Filipinas & 11,81 & $6,70 \mathrm{abr}$ & 4,79 \\
\hline Grécia & 16,27 & $16,59 \mathrm{abr}$. & $-0,27$ \\
\hline Hong Kong & 6,26 & $9,5^{\star \star}$ mar. & $-2,96$ \\
\hline Hungria & 35,75 & $48,93 \mathrm{abr}$. & $-8,85$ \\
\hline India & 11,40 & $0,00 \mathrm{fev}$ & 11,40 \\
\hline Indonésia & 16,00 & $14,53 \mathrm{abr}$. & 1,29 \\
\hline Israel & 11,70 & $2,84 \mathrm{abr}$ & 8,62 \\
\hline Malásia & 5,95 & $2,83 \mathrm{abr}$ & 3,04 \\
\hline México & 60,98 & $71,58 \mathrm{mar}$. & $-6,18$ \\
\hline Polônia & 28,03 & $35,12^{\star \star \star}$ mar. & $-5,24$ \\
\hline Portugal & 10,08 & $9,81 \mathrm{mar}$. & 0,25 \\
\hline República Tcheca & 9,95 & $8,66 \mathrm{abr}$ & 1,19 \\
\hline Rússia & 242,36 & 205,20 ** abr. & 12,18 \\
\hline Tailândia & 13,50 & $13,65 \mathrm{abr}$. & $-0,13$ \\
\hline Taiwan & 7,00 & $4,40^{\star \star}$ abr. & 2,49 \\
\hline Turquia & 75,59 & 88,42 abr. & $-6,81$ \\
\hline Venezuela & 17,50 & 46,53 abr. & $-19,81$ \\
\hline
\end{tabular}

(1) Taxas de juro de curto prazo em maio de1995; (2) Índices de preços ao consumidor. Corresponde, salvo indicação em contrário, à taxa de inflação anualizada do período de 3 meses, até março ou abril de 1995.

(*) INPC; $\left({ }^{* *}\right)$ Variação sobre igual mês do ano anterior; (***) Taxa de inflação anualizada do quadrimestre nov/94-mar/95.

Fontes: Dados brutos - Fundo Monetário Internacional, Instituto Brasileiro de Geografia e Estatistica, e The Economist. 
Tabela 17

Brasil: taxas de juro para empréstimo,1995-96

\begin{tabular}{|c|c|c|c|c|c|c|}
\hline \multicolumn{2}{|c|}{ Período } & \multicolumn{3}{|c|}{ Capital de giro } & \multicolumn{2}{|c|}{ Crédito pessoal } \\
\hline & & Nominal & Real $\left(^{\star}\right)$ & Real $\left({ }^{* \star}\right)$ & Nominal & Real $\left(^{*}\right)$ \\
\hline \multirow[t]{12}{*}{1995} & Jan. & 135,0 & 98,0 & 105,9 & 164,4 & 122,7 \\
\hline & Fev. & 115,8 & 91,3 & 94,5 & 161,2 & 131,5 \\
\hline & Mar. & 168,2 & 121,2 & 137,5 & 218,3 & 162,5 \\
\hline & Abr. & 163,5 & 96,2 & 109,0 & 215,6 & 134,9 \\
\hline & Mai. & 176,4 & 115,4 & 139,2 & 236,5 & 162,2 \\
\hline & Jun. & 168,2 & 107,1 & 123,8 & 224,6 & 150,6 \\
\hline & Jul. & 173,0 & 104,0 & 134,4 & 223,2 & 141,5 \\
\hline & Ago. & 160,6 & 130,7 & 145,5 & 211,8 & 176,0 \\
\hline & Set. & 143,6 & 111,8 & 102,0 & 204,1 & 164,4 \\
\hline & Out. & 132,9 & 97,1 & 115,7 & 182,2 & 138,8 \\
\hline & Nov. & 136,9 & 97,9 & 126,9 & 195,5 & 146,9 \\
\hline & Dez. & 123,5 & 83,6 & 115,1 & 168,5 & 120,7 \\
\hline \multirow[t]{6}{*}{1996} & Jan. & 101,7 & 69,5 & 96,7 & 167,1 & 124,4 \\
\hline & Fev. & 88,0 & 72,7 & 87,3 & 148,8 & 128,5 \\
\hline & Mar. & 79,0 & 72,9 & 82,2 & 132,9 & 125,0 \\
\hline & Abr. & 75,5 & 57,1 & 67,9 & 134,5 & 109,8 \\
\hline & Mai. & 72,7 & 48,3 & 68,0 & 133,4 & 100,4 \\
\hline & Jun. & 72,7 & 47,4 & 64,8 & 137,1 & 102,4 \\
\hline
\end{tabular}

(*) Deflator INPC (Índice Nacional de Preços ao Consumidor); (**) Deflator IPA — PI (Índice Preços por Atacado — Oferta Global — Preços da Indústria).

Fontes: Banco Central do Brasil, Banco Itaú e Fundação Getúlio Vargas. 


\section{Tabela 18}

Déficit do setor público brasileiro ${ }^{(1)}, 1992-96$

\begin{tabular}{|c|c|c|c|c|c|}
\hline \multicolumn{2}{|c|}{ Periodo } & \multirow{2}{*}{$\begin{array}{c}\text { Déficit } \\
\text { nominal } \\
44,14\end{array}$} & \multirow{2}{*}{$\begin{array}{c}\text { Déficit } \\
\text { operacional }^{(3)} \\
2,21\end{array}$} & \multirow{2}{*}{$\begin{array}{c}\begin{array}{c}\text { Juros } \\
\text { reais }^{(3)}\end{array} \\
4,53\end{array}$} & \multirow{2}{*}{$\begin{array}{c}\text { Déficit } \\
\text { primário } \\
\text {-2,32 }\end{array}$} \\
\hline 1992 & & & & & \\
\hline 1993 & & 58,41 & $-0,25$ & 2,39 & $-2,64$ \\
\hline 1994 & & 44,41 & $-1,34$ & 3,82 & $-5,16$ \\
\hline \multirow[t]{2}{*}{1995} & $1 \stackrel{0}{ } \mathrm{sem}^{(4)}$ & 5,49 & 2,33 & 4,53 & $-2,20$ \\
\hline & $\operatorname{ano}^{(4)}$ & 7,34 & 4,99 & 5,36 & $-0,37$ \\
\hline 1996 & $1^{\circ} \mathrm{sem}^{(4)}$ & 6,55 & 3,57 & 3,44 & 0,13 \\
\hline
\end{tabular}

(1) Inclui Governos federal, estaduais e municipais, Banco Central, empresas estatais federais, estaduais e municipais; (2) Reflete a relação dos fluxos com o PIB, ambos valorizados para o último mês do período com base no IGP-DI (Índice Geral de Preços — disponibilidade interna); (3) Deflator IGP-DI (centrado); (4) Dados preliminares; (+) Déficit (-) Superávit.

Fonte: Banco Central do Brasil. 


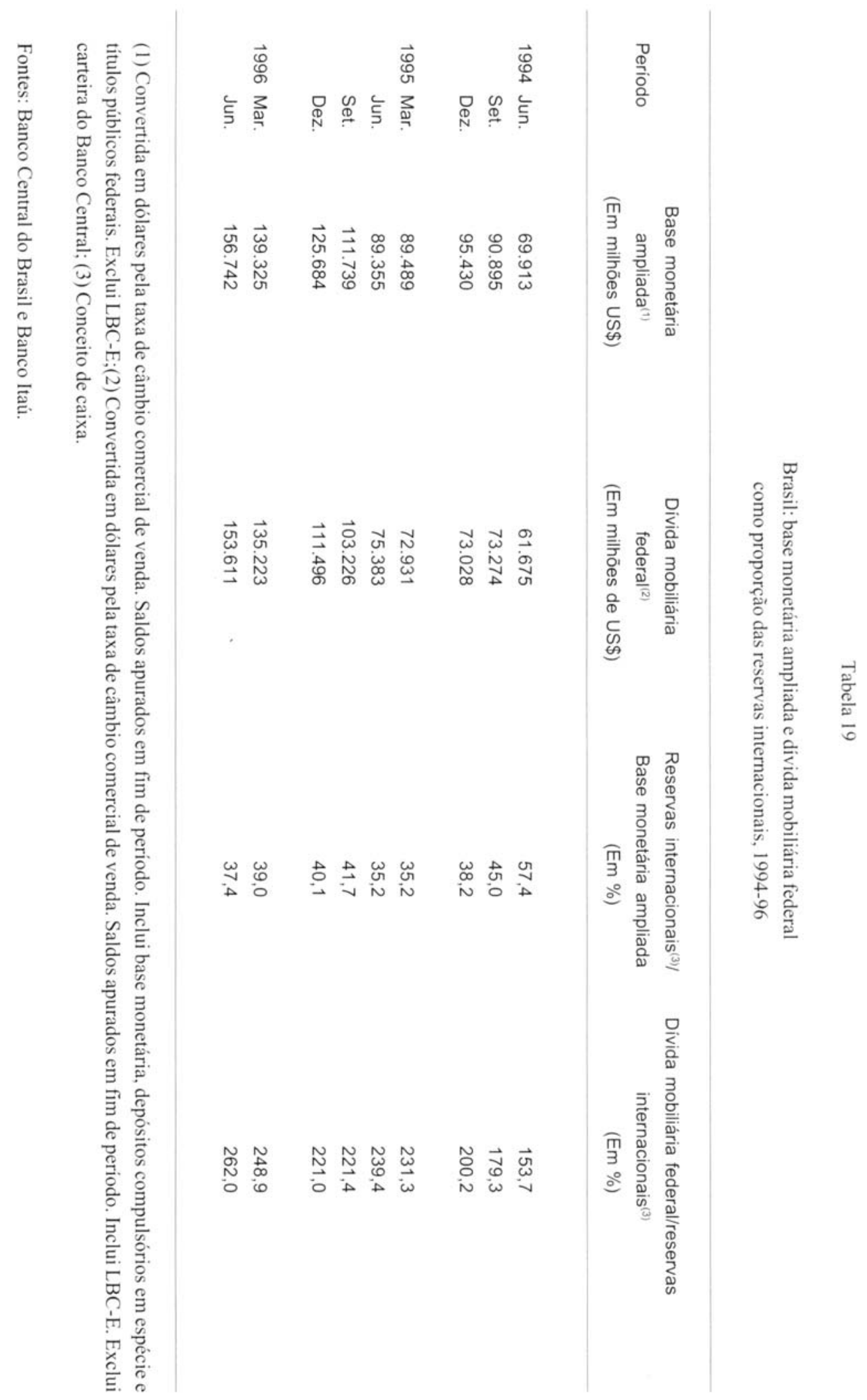

